Article

\title{
Catalytic Deoxygenation of Hexadecyl Palmitate as a Model Compound of Euglena Oil in $\mathrm{H}_{2}$ and $\mathrm{N}_{2}$ Atmospheres
}

\author{
Yanyong Liu * (D), Megumu Inaba and Koichi Matsuoka \\ National Institute of Advanced Industrial Science and Technology, AIST Tsukuba West, 16-1 Onogawa, Tsukuba, \\ Ibaraki 305-8569, Japan; mg.inaba@aist.go.jp (M.I.); koichi-matsuoka@aist.go.jp (K.M.) \\ * Correspondence: yy.ryuu@aist.go.jp; Tel.: +81-29-861-4826
}

Received: 15 October 2017; Accepted: 5 November 2017; Published: 9 November 2017

\begin{abstract}
Hexadecyl palmitate $\left(\mathrm{C}_{15} \mathrm{H}_{31} \mathrm{COOC}_{16} \mathrm{H}_{33}\right.$, used as a model compound for Euglena oil) was deoxygenated to hydrocarbons over various solid catalysts in autoclave reactors. In a $\mathrm{H}_{2}$ atmosphere, $1 \mathrm{wt} . \%$ of $\mathrm{Pd} / \mathrm{Mg}(\mathrm{Al}) \mathrm{O}$ catalyst, derived from a hydrotalcite precursor, yielded a $\mathrm{C}_{15} \mathrm{H}_{31} \mathrm{COOC}_{16} \mathrm{H}_{33}$ conversion close to $100 \%$, and a $\mathrm{C}_{10}-\mathrm{C}_{16}$ (aviation fuel range) hydrocarbon yield of $90.2 \%$ for the deoxygenation of $\mathrm{C}_{15} \mathrm{H}_{31} \mathrm{COOC}_{16} \mathrm{H}_{33}$ at $300{ }^{\circ} \mathrm{C}$ for $2 \mathrm{~h}$. In a $\mathrm{N}_{2}$ atmosphere, $1 \mathrm{wt} . \%$ of $\mathrm{Pd} / \mathrm{Mg}(\mathrm{Al}) \mathrm{O}$ catalyst yielded a $\mathrm{C}_{10}-\mathrm{C}_{16}$ hydrocarbon yield of $63.5 \%$, which was much higher than those obtained with $\mathrm{Mg}(\mathrm{Al}) \mathrm{O}(15.1 \%), \mathrm{H}-\mathrm{ZSM}-5$ (8.3\%), and $1 \mathrm{wt} . \% \mathrm{Pd} / \mathrm{C}(26.2 \%)$ for the deoxygenation of $\mathrm{C}_{15} \mathrm{H}_{31} \mathrm{COOC}_{16} \mathrm{H}_{33}$ at $300{ }^{\circ} \mathrm{C}$ for $2 \mathrm{~h}$. The Pd metal site and the solid base site in $\mathrm{Mg}(\mathrm{Al}) \mathrm{O}$ had a synergetic effect on the deoxygenation of $\mathrm{C}_{15} \mathrm{H}_{31} \mathrm{COOC}_{16} \mathrm{H}_{33}$ in $\mathrm{N}_{2}$ atmosphere over the $\mathrm{Pd} / \mathrm{Mg}(\mathrm{Al}) \mathrm{O}$ catalyst. By prolonging the reaction time to $5 \mathrm{~h}$ for reaction at $300{ }^{\circ} \mathrm{C}$ in $\mathrm{N}_{2}$ atmosphere, the yield of $\mathrm{C}_{10}-\mathrm{C}_{16}$ hydrocarbons increased to $80.4 \%$ with a $\mathrm{C}_{15} \mathrm{H}_{31} \mathrm{COOC}_{16} \mathrm{H}_{33}$ conversion of $99.1 \%$ over the $1 \mathrm{wt} . \% \mathrm{Pd} / \mathrm{Mg}(\mathrm{Al}) \mathrm{O}$ catalyst.
\end{abstract}

Keywords: hexadecyl palmitate; Euglena oil; deoxygenation; aviation fuel range hydrocarbons; hydrotalcite; $\mathrm{Pd}$ catalyst; $\mathrm{N}_{2}$ atmosphere; $\mathrm{H}_{2}$ atmosphere

\section{Introduction}

The production of chemicals and transport fuels from renewable biomass is a sustainable and environment-friendly way to reduce the world's dependence on crude oil. Starch and cellulose in wood can be converted to ethanol by yeast fermentation [1]. Lignin in wood and organic wastes can be converted to motor fuels by a biomass-to-liquid (BTL) process using a syngas platform [2,3]. Vegetable oils can be converted to fatty acid methyl esters (FAME, known as biodiesel) by transesterification with methanol [4]. Recently, the hydrotreatment of vegetable oils to produce hydrocarbon 'drop-in' fuels has attracted global research interest [5-7].

Algae oils have recently become a promising alternative feedstock for vegetable oils because the oil yields from algae are significantly higher than those from any other crop [8-11]. Euglena is a promising algae biomass because it is easily cultivated on a large scale. Most algae produce oils composed of triglycerides and fatty acids [8]. However, Euglena produces an oil wax that contains a mixture of saturated esters with long carbon chains $\left(\mathrm{C}_{m} \mathrm{H}_{2 m+1} \mathrm{COOC}_{n} \mathrm{H}_{2 n+1}, m=11-15, n=12-16\right)$ [12,13]. While some studies have been reported on the deoxygenation of triglycerides and fatty acids (vegetable oils and algae oils), very few studies have reported on the deoxygenation of fatty acid esters to date [14].

Metal (NiMo, Pt, etc.)-supported catalysts possess high activities for the deoxygenation of triglycerides and fatty acids in $\mathrm{H}_{2}$ atmosphere [15-17]. However, the deoxygenation of triglycerides in $\mathrm{N}_{2}$ atmosphere (without $\mathrm{H}_{2}$ ) is an important subject, because $\mathrm{H}_{2}$ is expensive and may be difficult to obtain in areas of vegetable and algae cultivation. Solid acids and bases have been reported as 
catalysts for the deoxygenation of triglycerides in $\mathrm{N}_{2}$ atmosphere [18-20]. Solid acid catalysts possess relatively high activities; however, hydrocarbons with long carbon chains (heavy hydrocarbons) crack on the acid sites [18]. This is unfortunate, because, in general, heavy hydrocarbons have a high value as chemicals and transport fuels. In contrast, the activities of solid base catalysts are relatively low; moreover, they exhibit relatively high selectivity for heavy hydrocarbons $[19,20]$. Pd supported on active carbon $(\mathrm{Pd} / \mathrm{C})$ has been reported as an effective catalyst for the catalytic deoxygenation of fatty acids and their esters in He atmosphere [14,21].

In this study, we chose hexadecyl palmitate $\left(\mathrm{C}_{15} \mathrm{H}_{31} \mathrm{COOC}_{16} \mathrm{H}_{33}\right)$ as a model compound of Euglena oil. We developed a highly active $\mathrm{Pd} / \mathrm{Mg}(\mathrm{Al}) \mathrm{O}$ catalyst (derived from Pd-containing MgAl-type hydrotalcite) for the deoxygenation of $\mathrm{C}_{15} \mathrm{H}_{31} \mathrm{COOC}_{16} \mathrm{H}_{33}$ to hydrocarbons in $\mathrm{H}_{2}$ and $\mathrm{N}_{2}$ atmospheres.

\section{Results and Discussion}

\subsection{Catalyst Characterization}

Figure 1 shows a structural model of the $\mathrm{Pd}_{0.016} \mathrm{Mg}_{3} \mathrm{Al}(\mathrm{OH})_{16} \mathrm{CO}_{3} \cdot x \mathrm{H}_{2} \mathrm{O}$ hydrotalcite used in this study. Hydrotalcite is a kind of anion clay with the general formula $\left[\mathrm{M}^{2+}{ }_{1-m} \mathrm{M}^{3+}{ }_{m}\right.$ $\left.(\mathrm{OH})_{2}\right]^{m+} \mathrm{A}^{n-}{ }_{m / n} \cdot x \mathrm{H}_{2} \mathrm{O}\left(\mathrm{M}^{2+}, \mathrm{M}^{3+}=\right.$ metal cations, $\mathrm{A}^{n-}=$ interlayer anion) [22]. The metal cations are distributed in brucite-like layers, and the interlayer anions are fixed between the brucite-like layers by electric charge interaction. The $\mathrm{M}^{2+}$ cation is usually $\mathrm{Mg}^{2+}$ and the $\mathrm{M}^{3+}$ cation is usually $\mathrm{Al}^{3+}$. The noble metal $\mathrm{Pd}^{2+}$ cation can be introduced into the $\mathrm{M}^{2+}$ position when $\mathrm{Pd}^{2+} /\left(\mathrm{M}^{2+}+\mathrm{M}^{3+}\right)<$ $5 \mathrm{mo} \%$ [23-25]. Basic MgAl-type hydrotalcite is the most common hydrotalcite, and has been used as an effective catalyst for some industrially important reactions [22-29].

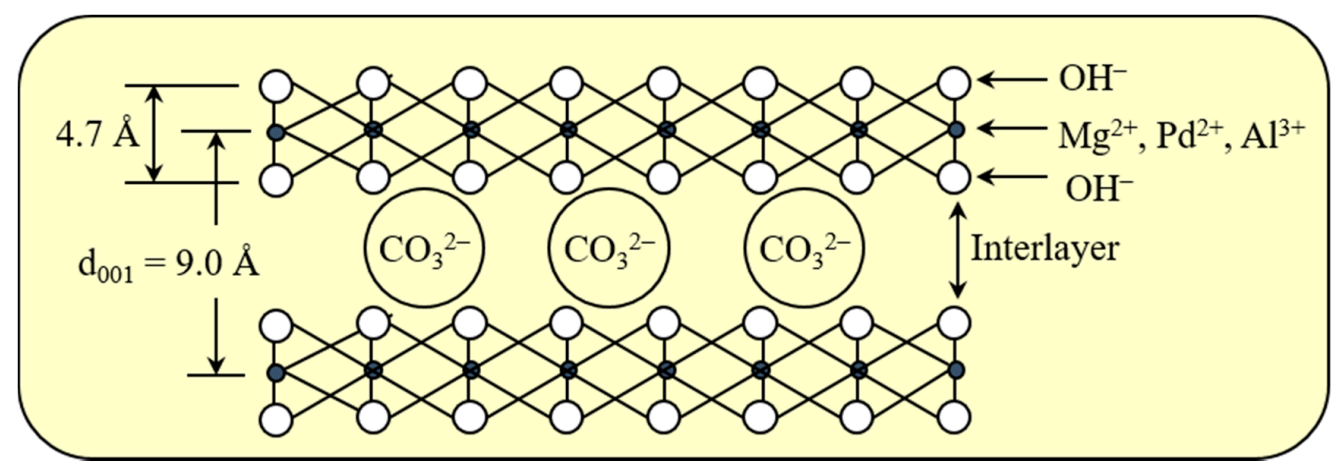

Figure 1. Structural model of the $\mathrm{Pd}_{0.016} \mathrm{Mg}_{3} \mathrm{Al}(\mathrm{OH})_{16} \mathrm{CO}_{3} \cdot x \mathrm{H}_{2} \mathrm{O}$ hydrotalcite used in this study.

Figure 2 shows X-ray diffraction (XRD) patterns of $\mathrm{Pd}_{0.016} \mathrm{Mg}_{3} \mathrm{Al}(\mathrm{OH})_{16} \mathrm{CO}_{3} \cdot x \mathrm{H}_{2} \mathrm{O}$ after drying at $100{ }^{\circ} \mathrm{C}$. By using a JICST database (from The Crystallographic Society of Japan) for identification, only the well-crystallized $\mathrm{Mg}_{3} \mathrm{Al}(\mathrm{OH})_{16} \mathrm{CO}_{3}$ phase was observed in the XRD pattern of $\mathrm{Pd}_{0.016} \mathrm{Mg}_{3} \mathrm{Al}(\mathrm{OH})_{16} \mathrm{CO}_{3} \cdot x \mathrm{H}_{2} \mathrm{O}$. The peaks of $\mathrm{Pd}(\mathrm{OH})_{2}$ and $\mathrm{PdO}$ phases could not be observed in the $\mathrm{XRD}$ pattern, probably because they formed amorphous phases. It is also possible that the $\mathrm{Pd}^{2+}$ ions entered the $\mathrm{Mg}^{2+}$ position in $\mathrm{Pd}_{0.016} \mathrm{Mg}_{3} \mathrm{Al}(\mathrm{OH})_{16} \mathrm{CO}_{3} \cdot x \mathrm{H}_{2} \mathrm{O}$ at a low Pd content [25]. The $d(001)$ (basal $d$ ) spacing at the lowest angle in the XRD pattern was $9.0 \AA$ for $\mathrm{Pd}_{0.016} \mathrm{Mg}_{3} \mathrm{Al}(\mathrm{OH})_{16} \mathrm{CO}_{3} \cdot x \mathrm{H}_{2} \mathrm{O}$. As shown in Figure 1, the thickness of the MgAl-type brucite-like layer was $4.7 \AA$ [22]. The gallery height was $4.3 \AA$ in $\mathrm{Pd}_{0.016} \mathrm{Mg}_{3} \mathrm{Al}(\mathrm{OH})_{16} \mathrm{CO}_{3} \cdot x \mathrm{H}_{2} \mathrm{O}$ after subtracting the thickness of the MgAl-type hydrotalcite layer $(4.7 \AA)$ from the basal $d$ spacing $(9.0 \AA)$. This gallery height $(4.3 \AA$ ) coincides with the size of the $\mathrm{CO}_{3}{ }^{2-}$ anion [22]. 


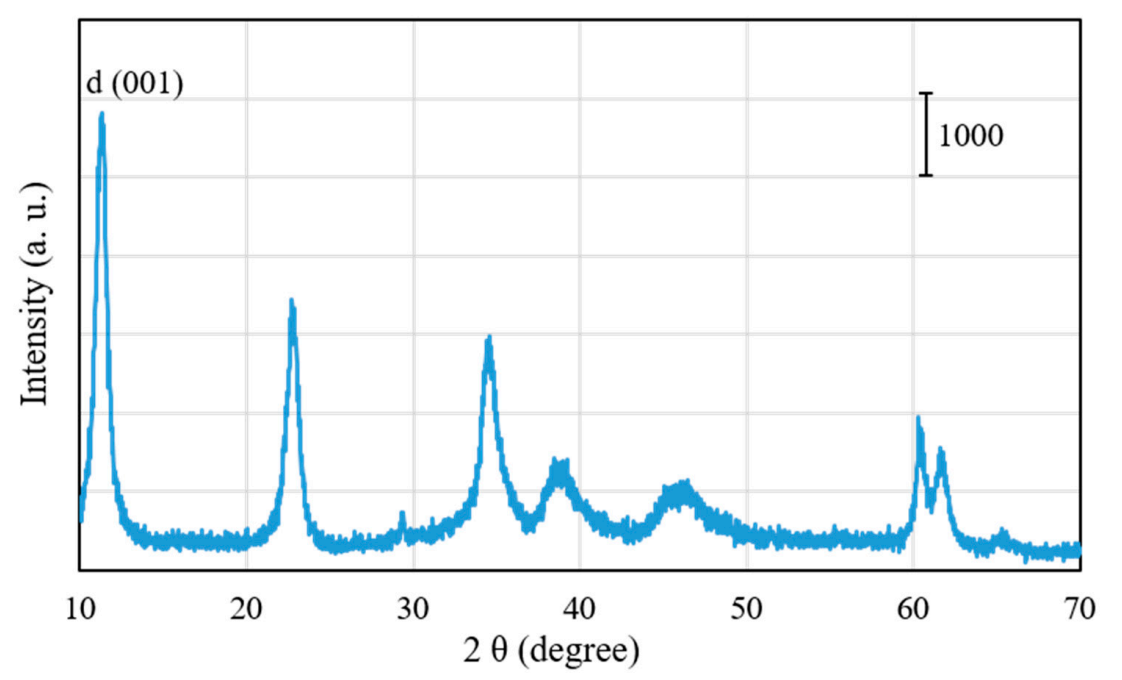

Figure 2. X-ray diffraction (XRD) patterns of $\mathrm{Pd}_{0.016} \mathrm{Mg}_{3} \mathrm{Al}(\mathrm{OH}){ }_{16} \mathrm{CO}_{3} \cdot x \mathrm{H}_{2} \mathrm{O}$ after drying at $100{ }^{\circ} \mathrm{C}$.

Figure 3 shows the thermogravimetric analysis (TGA) and differential thermal analysis (DTA) results for $\mathrm{Pd}_{0.016} \mathrm{Mg}_{3} \mathrm{Al}(\mathrm{OH})_{16} \mathrm{CO}_{3} \cdot x \mathrm{H}_{2} \mathrm{O}$ after drying at $100{ }^{\circ} \mathrm{C}$. Three stages of sudden weight loss can be observed in the TGA curve. The first sudden weight loss, which appears at below $200{ }^{\circ} \mathrm{C}$, was attributed to the loss of physically absorbed water and interlayer water. The second sudden weight loss, at $220-450{ }^{\circ} \mathrm{C}$, was attributed to the removal of $\mathrm{CO}_{2}$ from the interlayer carbonate anions and hydroxyl groups from the brucite-like layers. The third sudden weight loss, at $850-890{ }^{\circ} \mathrm{C}$, can be ascribed to the formation of the spinel-like phase of $\mathrm{MgAl}_{2} \mathrm{O}_{4}[20,24]$. The results of DTA and TGA nearly coincide. The endotherm band at $130^{\circ} \mathrm{C}$ in the DTA curve corresponds to the loss of physically absorbed water. After losing physically absorbed water, $\mathrm{Pd}_{0.016} \mathrm{Mg}_{3} \mathrm{Al}(\mathrm{OH})_{16} \mathrm{CO}_{3} \cdot x \mathrm{H}_{2} \mathrm{O}$ was converted to $\mathrm{Pd}_{0.016} \mathrm{Mg}_{3} \mathrm{Al}(\mathrm{OH})_{16} \mathrm{CO}_{3} \cdot 4 \mathrm{H}_{2} \mathrm{O}$. The endotherm band at $190{ }^{\circ} \mathrm{C}$ in the DTA curve corresponds to the loss of interlayer water. After losing interlayer water, $\mathrm{Pd}_{0.016} \mathrm{Mg}_{3} \mathrm{Al}(\mathrm{OH})_{16} \mathrm{CO}_{3} \cdot 4 \mathrm{H}_{2} \mathrm{O}$ was converted to $\mathrm{Pd}_{0.016} \mathrm{Mg}_{3} \mathrm{Al}(\mathrm{OH})_{16} \mathrm{CO}_{3}$. The endotherm band at $420{ }^{\circ} \mathrm{C}$ in the DTA curve corresponds to the loss of interlayer carbonate anions and hydroxyl groups in the brucite-like layers. The layered structure of hydrotalcite was destroyed upon calcination at $420{ }^{\circ} \mathrm{C}$, following which $\mathrm{Pd}_{0.016} \mathrm{Mg}_{3} \mathrm{Al}(\mathrm{OH})_{16} \mathrm{CO}_{3}$ was converted to a metal-oxide mixture $\mathrm{Pd}_{0.016} \mathrm{Mg}_{3} \mathrm{AlO}_{x}$, in which $\mathrm{Pd}^{2+}$ and $\mathrm{Al}^{3+}$ ions entered the $\mathrm{MgO}$ cubic lattices [22]. The small endotherm band at $860^{\circ} \mathrm{C}$ in the DTA curve corresponds to the solid phase change of the metal-oxide mixture to a spinel-like phase of $\mathrm{MgAl}_{2} \mathrm{O}_{4}$ and crystalline $\mathrm{MgO}$ [22].

Figure 4 shows the dependence of the Brunauer-Emmett-Teller (BET) surface area of $\mathrm{Pd}_{0.016} \mathrm{Mg}_{3} \mathrm{Al}(\mathrm{OH})_{16} \mathrm{CO}_{3} \cdot x \mathrm{H}_{2} \mathrm{O}$ on calcination temperature from $100{ }^{\circ} \mathrm{C}$ to $1000{ }^{\circ} \mathrm{C}$. Calcination was carried out at each temperature for $3 \mathrm{~h}$ in air. $\mathrm{Pd}_{0.016} \mathrm{Mg}_{3} \mathrm{Al}(\mathrm{OH})_{16} \mathrm{CO}_{3} \cdot x \mathrm{H}_{2} \mathrm{O}$ showed a BET surface area of $73 \mathrm{~m}^{2} / \mathrm{g}$ after calcination at $100{ }^{\circ} \mathrm{C}$. The BET surface area increased with an increasing calcination temperature from $100{ }^{\circ} \mathrm{C}$ to $450{ }^{\circ} \mathrm{C}$, and then decreased with increasing calcination temperature from $450{ }^{\circ} \mathrm{C}$ to $1000{ }^{\circ} \mathrm{C}$. The layered structure of $\mathrm{Pd}_{0.016} \mathrm{Mg}_{3} \mathrm{Al}(\mathrm{OH})_{16} \mathrm{CO}_{3}$ hydrotalcite was destroyed, and a $\mathrm{PdO}-\mathrm{Mg}(\mathrm{Al}) \mathrm{O}$ metal-oxide mixture was formed upon calcination at $450{ }^{\circ} \mathrm{C}$. In the process of destruction, the removal of $\mathrm{CO}_{2}$ (from the interlayer carbonate anions) and hydroxyl groups (from the brucite-like layers) created pores in the $\mathrm{PdO}-\mathrm{Mg}(\mathrm{Al}) \mathrm{O}$ metal-oxide mixture formed. These pores increased the BET surface area. Calcination at a temperature that was higher than $450{ }^{\circ} \mathrm{C}$ caused sintering of the metal-oxide mixture particles, which decreased the BET surface area. Moreover, an obvious decrease in the BET surface area was observed at $800-850{ }^{\circ} \mathrm{C}$. The formation of spinel-like phases of $\mathrm{MgAl}_{2} \mathrm{O}_{4}$ from the $\mathrm{PdO}-\mathrm{Mg}(\mathrm{Al}) \mathrm{O}$ metal-oxide mixture resulted in a decrease in the BET surface area upon calcination at $800-850{ }^{\circ} \mathrm{C}$ [25]. Because the highest BET surface area $\left(143 \mathrm{~m}^{2} / \mathrm{g}\right)$ was obtained for calcination at $450{ }^{\circ} \mathrm{C}$, we calcined $\mathrm{Pd}_{0.016} \mathrm{Mg}_{3} \mathrm{Al}(\mathrm{OH})_{16} \mathrm{CO}_{3} \cdot x \mathrm{H}_{2} \mathrm{O}$ at $450{ }^{\circ} \mathrm{C}$ for $3 \mathrm{~h}$ in air before use in this study. 


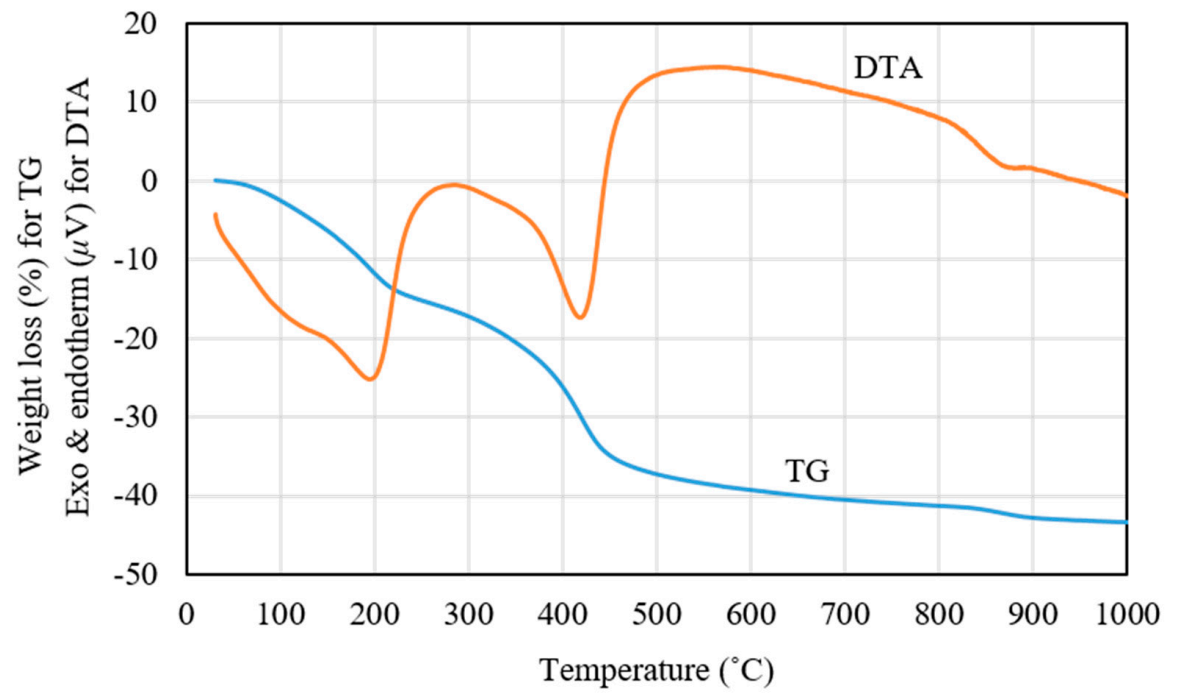

Figure 3. The thermogravimetric analysis (TGA) and differential thermal analysis (DTA) results for $\mathrm{Pd}_{0.016} \mathrm{Mg}_{3} \mathrm{Al}(\mathrm{OH})_{16} \mathrm{CO}_{3} \cdot x \mathrm{H}_{2} \mathrm{O}$ after drying at $100{ }^{\circ} \mathrm{C}$.

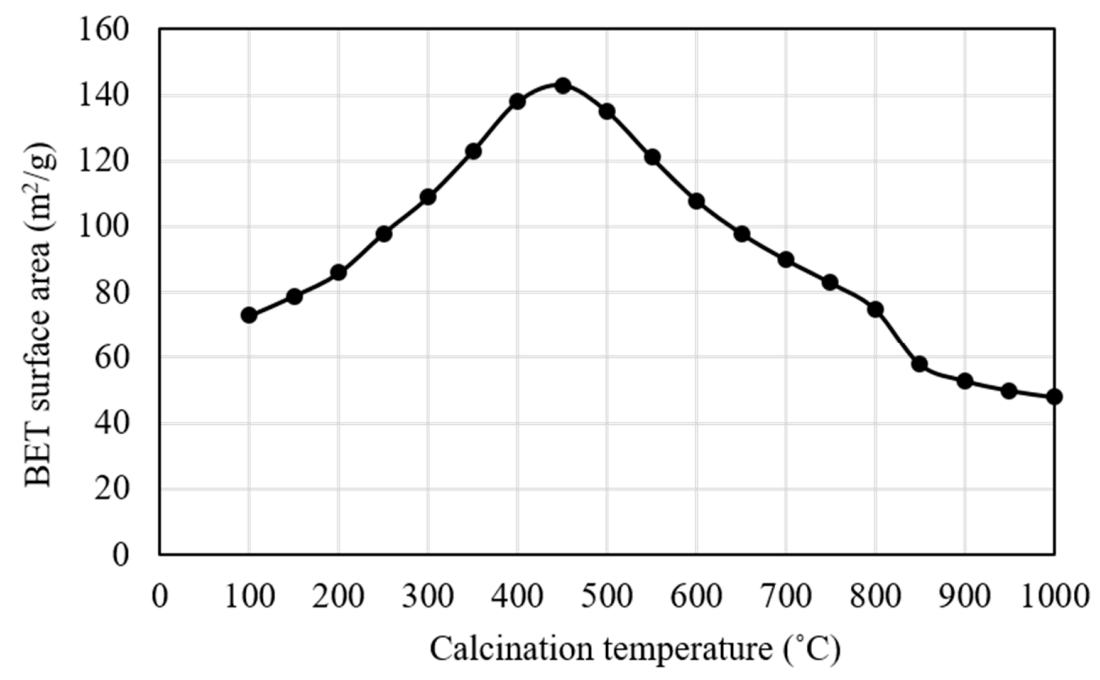

Figure 4. The Brunauer-Emmett-Teller (BET) surface area of $\mathrm{Pd}_{0.016} \mathrm{Mg}_{3} \mathrm{Al}(\mathrm{OH})_{16} \mathrm{CO}_{3} \cdot x \mathrm{H}_{2} \mathrm{O}$ on calcination temperature from $100{ }^{\circ} \mathrm{C}$ to $1000{ }^{\circ} \mathrm{C}$.

The use of uniform multicomponent precursors results in well-dispersed metal particles on the surface of supports after calcination and reduction. This method, known as "solid phase crystallization" (SPC), is important in the preparation of highly active metal-supported catalysts [27-35]. In this study, $\mathrm{Pd}^{2+}$ could enter the $\mathrm{Mg}^{2+}$ position in $\mathrm{Pd}_{0.016} \mathrm{Mg}_{3} \mathrm{Al}(\mathrm{OH})_{16} \mathrm{CO}_{3} \cdot x \mathrm{H}_{2} \mathrm{O}$ hydrotalcite after drying at $100{ }^{\circ} \mathrm{C}$ in air. As a result, a well-distributed mixed oxide, $\mathrm{PdO}-\mathrm{Mg}(\mathrm{Al}) \mathrm{O}$, could be formed after calcining $\mathrm{Pd}_{0.016} \mathrm{Mg}_{3} \mathrm{Al}(\mathrm{OH})_{16} \mathrm{CO}_{3} \cdot x \mathrm{H}_{2} \mathrm{O}$ at $450{ }^{\circ} \mathrm{C}$ in air. Finally, a $\mathrm{Pd} / \mathrm{Mg}(\mathrm{Al}) \mathrm{O}$ catalyst with highly dispersed $\mathrm{Pd}$ metal particles and strong interaction between the metal and support could be obtained after the pretreatment process of $\mathrm{H}_{2}$ flow reduction.

\subsection{Catalytic Deoxygenation of $\mathrm{C}_{15} \mathrm{H}_{31} \mathrm{COOC}_{16} \mathrm{H}_{33}$ in $\mathrm{H}_{2}$ Atmosphere}

Figure 5 shows the flame ionization detector-gas chromatography (FID-GC) charts of $\mathrm{C}_{15} \mathrm{H}_{31} \mathrm{COOC}_{16} \mathrm{H}_{33}$ and the liquid product formed upon deoxygenation of $\mathrm{C}_{15} \mathrm{H}_{31} \mathrm{COOC}_{16} \mathrm{H}_{33}$ in $\mathrm{H}_{2}$ atmosphere, at $300{ }^{\circ} \mathrm{C}$, for $2 \mathrm{~h}$, over $1 \mathrm{wt} . \% \mathrm{Pd} / \mathrm{Mg}(\mathrm{Al}) \mathrm{O}$ catalyst. As shown in Figure $5 \mathrm{~B}$, the reactant $\left(\mathrm{C}_{15} \mathrm{H}_{31} \mathrm{COOC}_{16} \mathrm{H}_{33}\right)$ peak is not observed in the GC chart after reaction at $300{ }^{\circ} \mathrm{C}$ for $2 \mathrm{~h}$. The liquid 
products were almost saturated hydrocarbons $n-\mathrm{C}_{16} \mathrm{H}_{34}$ and $n-\mathrm{C}_{15} \mathrm{H}_{32}$. By calculating the amount of each component in the product using the GC chart, the molar ratio of $n-\mathrm{C}_{16} \mathrm{H}_{34}$ to $n-\mathrm{C}_{15} \mathrm{H}_{32}$ in the liquid product was found to be 4.3 .
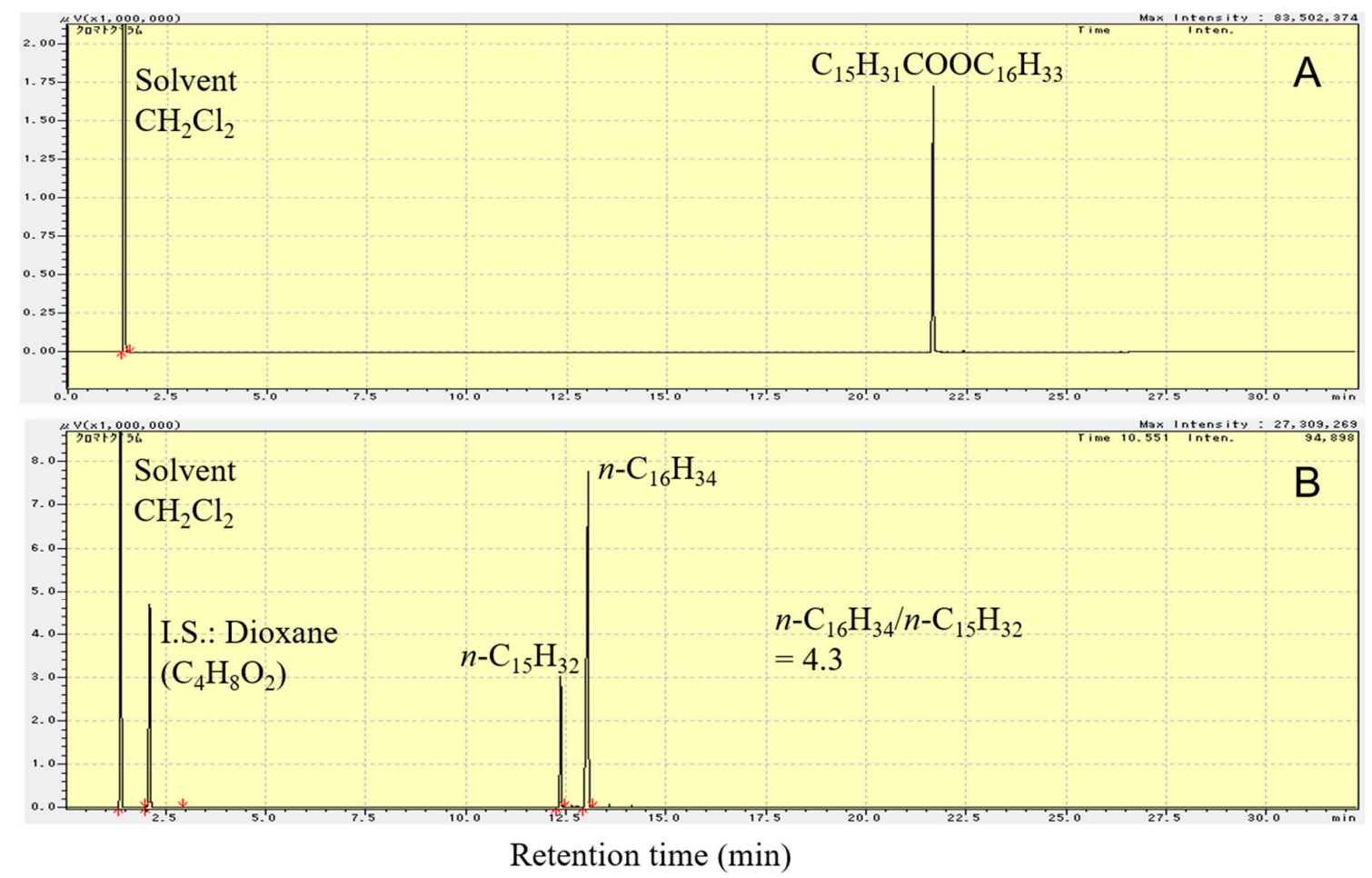

Figure 5. The flame ionization detector-gas chromatography (FID-GC) charts of $\mathrm{C}_{15} \mathrm{H}_{31} \mathrm{COOC}_{16} \mathrm{H}_{33}$ (A) and the liquid product formed upon deoxygenation of $\mathrm{C}_{15} \mathrm{H}_{31} \mathrm{COOC}_{16} \mathrm{H}_{33}$ in $\mathrm{H}_{2}$ atmosphere, at $300{ }^{\circ} \mathrm{C}$, for $2 \mathrm{~h}$, over $1 \mathrm{wt} . \% \mathrm{Pd} / \mathrm{Mg}(\mathrm{Al}) \mathrm{O}$ catalyst (B). Reaction conditions: $\mathrm{C}_{15} \mathrm{H}_{31} \mathrm{COOC}_{16} \mathrm{H}_{33}: 5 \mathrm{~g}$; catalyst: $0.2 \mathrm{~g}$; and, $\mathrm{H}_{2}$ pressure at $25^{\circ} \mathrm{C}: 0.9 \mathrm{MPa}$.

As shown in Reactions (1)-(3), deoxygenation of saturated fatty acids (such as stearic acid $\mathrm{C}_{17} \mathrm{H}_{35} \mathrm{COOH}$ ) involves three parallel reactions: reduction, decarbonylation, and decarboxylation [7]. For a fatty acid having an even number of carbons, reduction produces a normal paraffin having an even number of carbons plus water; decarbonylation produces a normal paraffin having an odd number of carbons plus water and $\mathrm{CO}$; and, decarboxylation produces a normal paraffin having an odd number of carbons plus $\mathrm{CO}_{2}$.

$$
\begin{gathered}
\mathrm{C}_{17} \mathrm{H}_{35} \mathrm{COOH}+3 \mathrm{H}_{2}=\mathrm{C}_{18} \mathrm{H}_{38}+2 \mathrm{H}_{2} \mathrm{O} \text { Reduction } \\
\mathrm{C}_{17} \mathrm{H}_{35} \mathrm{COOH}+\mathrm{H}_{2}=\mathrm{C}_{17} \mathrm{H}_{36}+\mathrm{CO}+\mathrm{H}_{2} \mathrm{O} \text { Decarbonylation } \\
\mathrm{C}_{17} \mathrm{H}_{35} \mathrm{COOH}=\mathrm{C}_{17} \mathrm{H}_{36}+\mathrm{CO}_{2} \text { Decarboxylation }
\end{gathered}
$$

Based on Reactions (1)-(3), we believe that the deoxygenation of $\mathrm{C}_{15} \mathrm{H}_{31} \mathrm{COOC}_{16} \mathrm{H}_{33}$ in $\mathrm{H}_{2}$ atmosphere over $1 \mathrm{wt} . \% \mathrm{Pd} / \mathrm{Mg}(\mathrm{Al}) \mathrm{O}$ also involves three parallel reactions: reduction (Reaction (4)), decarbonylation (Reaction (5)), and decarboxylation (Reaction (6)).

$$
\begin{gathered}
\mathrm{C}_{15} \mathrm{H}_{31} \mathrm{COOC}_{16} \mathrm{H}_{33}+4 \mathrm{H}_{2}=2 \mathrm{C}_{16} \mathrm{H}_{34}+2 \mathrm{H}_{2} \mathrm{O} \text { Reduction } \\
\mathrm{C}_{15} \mathrm{H}_{31} \mathrm{COOC}_{16} \mathrm{H}_{33}+2 \mathrm{H}_{2}=\mathrm{C}_{15} \mathrm{H}_{32}+\mathrm{C}_{16} \mathrm{H}_{34}+\mathrm{CO}+\mathrm{H}_{2} \mathrm{O} \text { Decarbonylation } \\
\mathrm{C}_{15} \mathrm{H}_{31} \mathrm{COOC}_{16} \mathrm{H}_{33}+\mathrm{H}_{2}=\mathrm{C}_{15} \mathrm{H}_{32}+\mathrm{C}_{16} \mathrm{H}_{34}+\mathrm{CO}_{2} \text { Decarboxylation }
\end{gathered}
$$


As shown in Reactions (4)-(6), the reduction of one $\mathrm{C}_{15} \mathrm{H}_{31} \mathrm{COOC}_{16} \mathrm{H}_{33}$ molecule produces two $\mathrm{C}_{16} \mathrm{H}_{34}$ molecules. On the other hand, either decarbonylation or decarboxylation of one $\mathrm{C}_{15} \mathrm{H}_{31} \mathrm{COOC}_{16} \mathrm{H}_{33}$ molecule produces one $\mathrm{C}_{16} \mathrm{H}_{34}$ molecule and one $\mathrm{C}_{15} \mathrm{H}_{32}$ molecule. The decarbonylation of $\mathrm{C}_{15} \mathrm{H}_{31} \mathrm{COOC}_{16} \mathrm{H}_{33}$ produces $\mathrm{CO}$, whereas the decarboxylation of $\mathrm{C}_{15} \mathrm{H}_{31} \mathrm{COOC}_{16} \mathrm{H}_{33}$ produces $\mathrm{CO}_{2}$. Both $\mathrm{CO}$ and $\mathrm{CO}_{2}$ were detected in the gas product from the reaction over $1 \mathrm{wt} . \% \mathrm{Pd} / \mathrm{Mg}(\mathrm{Al}) \mathrm{O}$ catalyst, indicating that both decarbonylation of $\mathrm{C}_{15} \mathrm{H}_{31} \mathrm{COOC}_{16} \mathrm{H}_{33}$ (Reaction (5)) and decarboxylation of $\mathrm{C}_{15} \mathrm{H}_{31} \mathrm{COOC}_{16} \mathrm{H}_{33}$ (Reaction (6)) occurred during the reaction. Moreover, among Reactions (4)-(6), the reduction of $\mathrm{C}_{15} \mathrm{H}_{31} \mathrm{COOC}_{16} \mathrm{H}_{33}$ (Reaction (4)) was the main reaction, because the quantity of $n-\mathrm{C}_{16} \mathrm{H}_{34}$ in the liquid product was much more than that of $n-\mathrm{C}_{15} \mathrm{H}_{32}$ (Figure $5 \mathrm{~B}$ ).

For deoxygenation of $\mathrm{C}_{15} \mathrm{H}_{31} \mathrm{COOC}_{16} \mathrm{H}_{33}$ in $\mathrm{H}_{2}$ atmosphere, the metal site alone could achieve a high activity, because deoxygenation was carried out via three routes: reduction, decarbonylation, and decarboxylation. We used an acid support for the metal in order to adjust the selectivity of the hydrocarbon products during deoxygenation in $\mathrm{H}_{2}$ atmosphere [6,7]. In this study, we used a base support $(\mathrm{Mg}(\mathrm{Al}) \mathrm{O})$ for the metal (Pd) in order to suppress the hydrocracking of $n-\mathrm{C}_{15} \mathrm{H}_{32}$ and $n-\mathrm{C}_{16} \mathrm{H}_{34}$ products (to light hydrocarbons) during deoxygenation of $\mathrm{C}_{15} \mathrm{H}_{31} \mathrm{COOC}_{16} \mathrm{H}_{33}$ in $\mathrm{H}_{2}$ atmosphere.

Figure 6 shows X-ray diffraction (XRD) patterns of $1 \mathrm{wt} . \% \mathrm{Pd} / \mathrm{Mg}(\mathrm{Al}) \mathrm{O}$ catalyst before reaction and after reaction (for deoxygenation of $\mathrm{C}_{15} \mathrm{H}_{31} \mathrm{COOC}_{16} \mathrm{H}_{33}$ in $\mathrm{H}_{2}$ atmosphere at $300{ }^{\circ} \mathrm{C}$ for $2 \mathrm{~h}$ ). The sample before reaction was obtained by calcining $\mathrm{Pd}_{0.016} \mathrm{Mg}_{3} \mathrm{Al}(\mathrm{OH})_{16} \mathrm{CO}_{3} \cdot x \mathrm{H}_{2} \mathrm{O}$ in air at $450{ }^{\circ} \mathrm{C}$ for $3 \mathrm{~h}$, and then reducing in $\mathrm{H}_{2}$ at $300{ }^{\circ} \mathrm{C}$ for $1 \mathrm{~h}$. The XRD pattern of the sample before reaction proved the formation of mixed $\mathrm{Mg}-\mathrm{Al}$ oxides phases, indicating that the decomposition of the layered structure occurred after calcination and reduction. The reflections in XRD pattern at about $43^{\circ}$ and $63^{\circ}$ corresponded to $\mathrm{MgO}-$ like phase (periclase), or rather $\mathrm{MgO}-\mathrm{Al}_{2} \mathrm{O}_{3}$ solid solution $\mathrm{Mg}(\mathrm{Al}) \mathrm{O}$ [22] . The reflection of $\mathrm{Al}_{2} \mathrm{O}_{3}$ phase at $23^{\circ}$ was very small, indicating that $\mathrm{Al}^{3+}$ cations were dispersed in the structure of $\mathrm{MgO}$ without the formation of spinel species. Because the Pd loading was low (1 wt.\%) in the $\mathrm{Pd} / \mathrm{Mg}(\mathrm{Al}) \mathrm{O}$ catalyst, the metal Pd crystals certainly formed in very small sizes, and thus the metal $\mathrm{Pd}$ phase could not be detected in the XRD pattern. The sample after reaction was obtained by filtrating out liquid products, and then drying in vacuum at room temperature for $10 \mathrm{~h}$. From a comparison of the XRD pattern of $\mathrm{Pd} / \mathrm{Mg}(\mathrm{Al}) \mathrm{O}$ catalyst before reaction, no obvious change could be observed in the XRD patterns of $\mathrm{Pd} / \mathrm{Mg}(\mathrm{Al}) \mathrm{O}$ catalyst after reaction in $\mathrm{H}_{2}$ atmosphere at $300{ }^{\circ} \mathrm{C}$ for $2 \mathrm{~h}$.

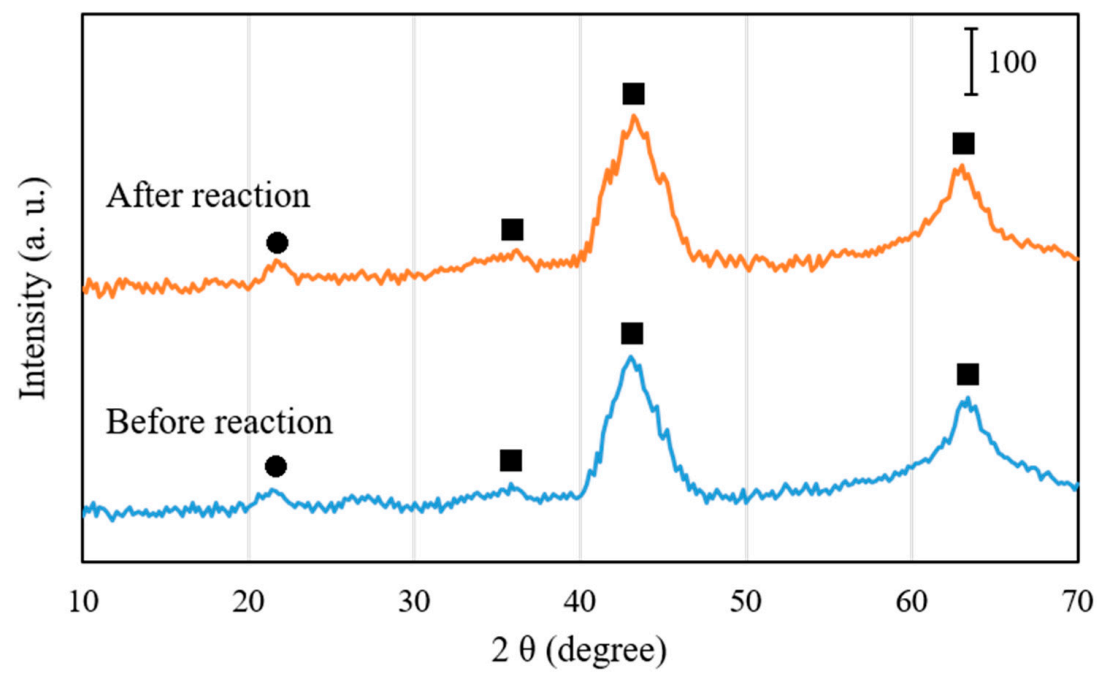

Figure 6. X-ray diffraction (XRD) patterns of $1 \mathrm{wt}$. $\% \mathrm{Pd} / \mathrm{Mg}(\mathrm{Al}) \mathrm{O}$ catalyst before reaction and after reaction (for deoxygenation of $\mathrm{C}_{15} \mathrm{H}_{31} \mathrm{COOC}_{16} \mathrm{H}_{33}$ in $\mathrm{H}_{2}$ atmosphere at $300{ }^{\circ} \mathrm{C}$ for $2 \mathrm{~h}$ ). $\mathbf{\square}, \mathrm{MgO}$; •, $\mathrm{Al}_{2} \mathrm{O}_{3}$. 
Figure 7 shows the dependence of $\mathrm{C}_{15} \mathrm{H}_{31} \mathrm{COOC}_{16} \mathrm{H}_{33}$ conversion and $\mathrm{C}_{10}-\mathrm{C}_{16}$ hydrocarbon yield on the reaction time for the catalytic deoxygenation of $\mathrm{C}_{15} \mathrm{H}_{31} \mathrm{COOC}_{16} \mathrm{H}_{33}$ in $\mathrm{H}_{2}$ atmosphere, at $300{ }^{\circ} \mathrm{C}$, over $1 \mathrm{wt} . \% \mathrm{Pd} / \mathrm{Mg}(\mathrm{Al}) \mathrm{O}$ catalyst. Four autoclave reactors were charged with the same reactant gases and the same amount of catalyst, and then operated at the same temperature $\left(300^{\circ} \mathrm{C}\right)$. The reaction in each autoclave reactor was finished in an hour. The products were analysed to determine the $\mathrm{C}_{15} \mathrm{H}_{31} \mathrm{COOC}_{16} \mathrm{H}_{33}$ conversion and the $\mathrm{C}_{10}-\mathrm{C}_{16}$ hydrocarbon yield at that reaction time. The yield of $\mathrm{C}_{10}-\mathrm{C}_{16}$ hydrocarbons is important as they can be used as aviation fuel [16]. As shown in Figure 7 , $\mathrm{C}_{15} \mathrm{H}_{31} \mathrm{COOC}_{16} \mathrm{H}_{33}$ conversion increased with the reaction time, and approached $100 \%$ after reaction for $2 \mathrm{~h}$ in $\mathrm{H}_{2}$ atmosphere. $\mathrm{CO}$ and $\mathrm{CO}_{2}$, which formed from decarbonylation and decarboxylation of $\mathrm{C}_{15} \mathrm{H}_{31} \mathrm{COOC}_{16} \mathrm{H}_{33}$ (Reactions (5) and (6)) were the main by-products in the deoxygenation of $\mathrm{C}_{15} \mathrm{H}_{31} \mathrm{COOC}_{16} \mathrm{H}_{33}$ in $\mathrm{H}_{2}$ atmosphere [6,7]. The amounts of formed $\mathrm{CO}$ and $\mathrm{CO}_{2}$ almost kept constant after reaction for $2 \mathrm{~h}$. A small amount of $\mathrm{C}_{1}-\mathrm{C}_{4}$ gaseous hydrocarbons was also formed during the reaction in $\mathrm{H}_{2}$ atmosphere, and the amount of $\mathrm{C}_{1}-\mathrm{C}_{4}$ gaseous hydrocarbons increased with prolonging the reaction time. As shown in Figure 7 , the yield of $C_{1}-C_{16}$ hydrocarbons increased to $90.2 \%$ after reaction for $2 \mathrm{~h}$, and then decreased slightly with prolonging reaction time due to the formation of light hydrocarbons $\left(<\mathrm{C}_{9}\right)$. On the whole, the $\mathrm{Pd} / \mathrm{Mg}(\mathrm{Al}) \mathrm{O}$ catalyst provided a high catalytic performance for the catalytic deoxygenation of $\mathrm{C}_{15} \mathrm{H}_{31} \mathrm{COOC}_{16} \mathrm{H}_{33}$ to hydrocarbons in $\mathrm{H}_{2}$ atmosphere.

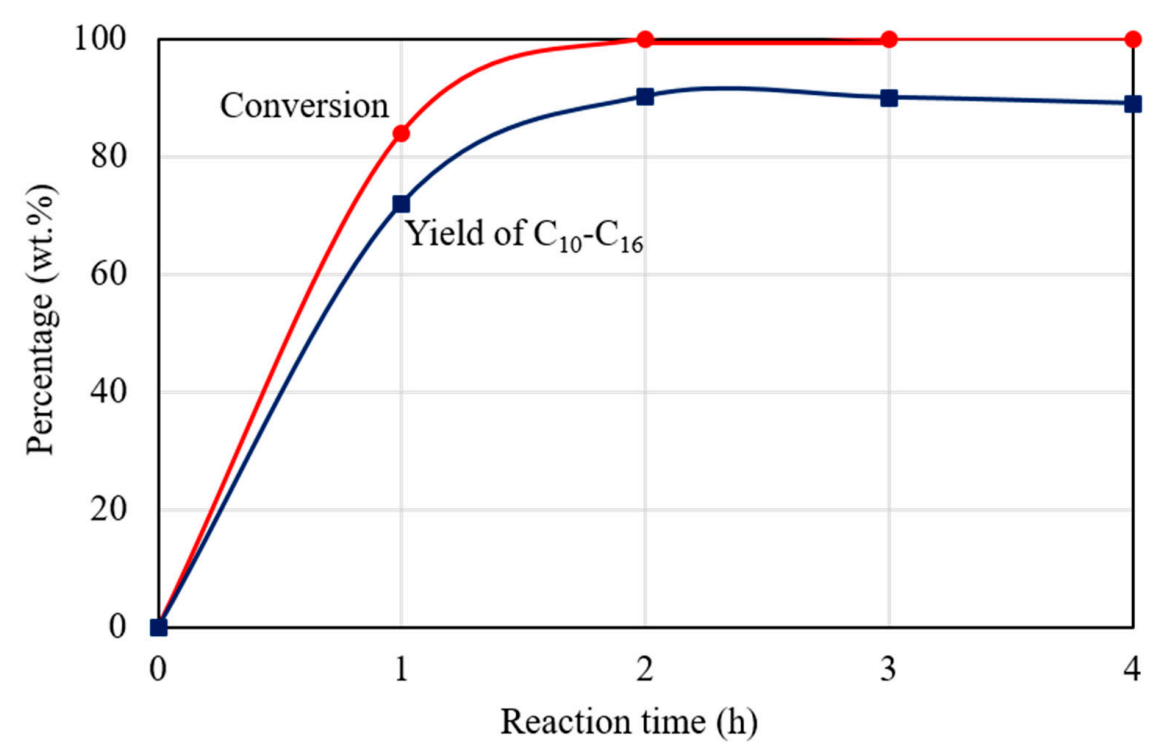

Figure 7. The dependence of $\mathrm{C}_{15} \mathrm{H}_{31} \mathrm{COOC}_{16} \mathrm{H}_{33}$ conversion and $\mathrm{C}_{10}-\mathrm{C}_{16}$ hydrocarbon yield on the reaction time for the catalytic deoxygenation of $\mathrm{C}_{15} \mathrm{H}_{31} \mathrm{COOC}_{16} \mathrm{H}_{33}$ in $\mathrm{H}_{2}$ atmosphere, at $300{ }^{\circ} \mathrm{C}$, over 1 wt. $\%$ Pd $/ \mathrm{Mg}(\mathrm{Al}) \mathrm{O}$ catalyst. Reaction conditions: $\mathrm{C}_{15} \mathrm{H}_{31} \mathrm{COOC}_{16} \mathrm{H}_{33}: 5$ g; catalyst: $0.2 \mathrm{~g} ; \mathrm{H}_{2}$ pressure at $25^{\circ} \mathrm{C}$ : $0.9 \mathrm{MPa}$.

\subsection{Catalytic Deoxygenation of $\mathrm{C}_{15} \mathrm{H}_{31} \mathrm{COOC}_{16} \mathrm{H}_{33}$ in $\mathrm{N}_{2}$ Atmosphere}

Table 1 shows the $\mathrm{C}_{15} \mathrm{H}_{31} \mathrm{COOC}_{16} \mathrm{H}_{33}$ conversion and $\mathrm{C}_{10}-\mathrm{C}_{16}$ hydrocarbons yield of the deoxygenation of $\mathrm{C}_{15} \mathrm{H}_{31} \mathrm{COOC}_{16} \mathrm{H}_{33}$ in $\mathrm{N}_{2}$ atmosphere at $300{ }^{\circ} \mathrm{C}$ for $2 \mathrm{~h}$ over various catalysts. The $1 \mathrm{wt} . \% \mathrm{Pd} / \mathrm{Mg}(\mathrm{Al}) \mathrm{O}$ catalyst resulted in a $\mathrm{C}_{15} \mathrm{H}_{31} \mathrm{COOC}_{16} \mathrm{H}_{33}$ conversion of $76.4 \%$ and a $\mathrm{C}_{10}-\mathrm{C}_{16}$ yield of $63.5 \%$ for the reaction at $300{ }^{\circ} \mathrm{C}$ for $2 \mathrm{~h}$ in $\mathrm{N}_{2}$ atmosphere. Both, $\mathrm{C}_{15} \mathrm{H}_{31} \mathrm{COOC}_{16} \mathrm{H}_{33}$ conversion and the $\mathrm{C}_{10}-\mathrm{C}_{16}$ yield obtained in $\mathrm{N}_{2}$ atmosphere, were much lower than those obtained in $\mathrm{H}_{2}$ atmosphere (Figure 6) over $\mathrm{Pd} / \mathrm{Mg}(\mathrm{Al}) \mathrm{O}$ after reaction at $300{ }^{\circ} \mathrm{C}$ for $2 \mathrm{~h}$. This indicates that $\mathrm{H}_{2}$ greatly improves the deoxygenation of $\mathrm{C}_{15} \mathrm{H}_{31} \mathrm{COOC}_{16} \mathrm{H}_{33}$, and that it is difficult to produce hydrocarbons from $\mathrm{C}_{15} \mathrm{H}_{31} \mathrm{COOC}_{16} \mathrm{H}_{33}$ in $\mathrm{N}_{2}$ atmosphere. The use of basic hydrotalcite, acidic $\mathrm{H}-\mathrm{ZSM}-5$, and $\mathrm{Pd} / \mathrm{C}$ has been reported for the deoxygenation of triglycerides or fatty acids in $\mathrm{N}_{2}$ or Ar atmospheres $[14,17,18]$. As shown in Table 1, the basic catalyst $\mathrm{Mg}(\mathrm{Al}) \mathrm{O}$ without Pd gave low conversion (23.3\%) and a low 
yield of $\mathrm{C}_{10}-\mathrm{C}_{16}$ hydrocarbons (15.1\%) for the reaction in $\mathrm{N}_{2}$ atmosphere. In contrast, the conversion was relatively high $(55.6 \%)$, but the yield of $\mathrm{C}_{10}-\mathrm{C}_{16}$ hydrocarbons was very low $(8.3 \%)$ over the acidic catalyst H-ZSM-5. Heavy hydrocarbons formed in the reaction cracked to light hydrocarbons on the acidic sites of H-ZSM- 5 during the reaction. The use of $\mathrm{Pd} / \mathrm{C}$ resulted in a $\mathrm{C}_{15} \mathrm{H}_{31} \mathrm{COOC}_{16} \mathrm{H}_{33}$ conversion of $41.7 \%$ and a $\mathrm{C}_{10}-\mathrm{C}_{16}$ hydrocarbons yield of $26.2 \%$ for the reaction at $300{ }^{\circ} \mathrm{C}$ for $2 \mathrm{~h}$ in $\mathrm{N}_{2}$ atmosphere. Therefore, $\mathrm{Pd} / \mathrm{Mg}(\mathrm{Al}) \mathrm{O}$ shows a much higher catalytic performance than these catalysts that are reported in the literature, for the deoxygenation of $\mathrm{C}_{15} \mathrm{H}_{31} \mathrm{COOC}_{16} \mathrm{H}_{33}$ in $\mathrm{N}_{2}$ atmosphere. The development of multi-functional catalysts to improve catalyst performance is an important challenge in the catalyst field. The catalyst containing Pt metal and basic hydrotalcite has been reported as excellent for the aromatization of n-hexane [26]. We had developed some multi-functional catalysts containing metal and solid acid for some industrially important reactions [36-42]. Pd metal sites and solid base sites (in $\mathrm{Mg}(\mathrm{Al}) \mathrm{O}$ ) achieved a synergetic effect for the deoxygenation of $\mathrm{C}_{15} \mathrm{H}_{31} \mathrm{COOC}_{16} \mathrm{H}_{33}$ in $\mathrm{N}_{2}$ atmosphere over the $\mathrm{Pd} / \mathrm{Mg}(\mathrm{Al}) \mathrm{O}$ catalyst.

Table 1. The $\mathrm{C}_{15} \mathrm{H}_{31} \mathrm{COOC}_{16} \mathrm{H}_{33}$ conversion and $\mathrm{C}_{10}-\mathrm{C}_{16}$ hydrocarbons yield of the deoxygenation of $\mathrm{C}_{15} \mathrm{H}_{31} \mathrm{COOC}_{16} \mathrm{H}_{33}$ in $\mathrm{N}_{2}$ atmosphere at $300{ }^{\circ} \mathrm{C}$ for $2 \mathrm{~h}$ over various catalysts ${ }^{\mathrm{a}}$.

\begin{tabular}{cccccc}
\hline \multirow{2}{*}{ Catalyst } & \multirow{2}{*}{ Conversion (\%) } & \multicolumn{4}{c}{ Yield (\%) } \\
\cline { 3 - 6 } & & $\mathbf{C}_{\mathbf{1}}-\mathrm{C}_{\mathbf{4}}$ & $\mathbf{C}_{\mathbf{5}}-\mathbf{C}_{\mathbf{9}}$ & $\mathbf{C}_{\mathbf{1 0}}-\mathrm{C}_{\mathbf{1 6}}$ & $\mathbf{C O}_{\mathbf{2}}$ \\
\hline $\mathrm{Pd} / \mathrm{Mg}(\mathrm{Al}) \mathrm{O}^{\mathrm{b}}$ & 76.4 & 1.4 & 3.6 & 63.5 & 4.8 \\
$\mathrm{Mg}(\mathrm{Al}) \mathrm{O}$ & 23.3 & 0.5 & 1.7 & 15.1 & 1.6 \\
$\mathrm{H}-\mathrm{ZSM}-5$ & 55.6 & 5.8 & 26.3 & 8.3 & 3.1 \\
$\mathrm{Pd} / \mathrm{C}^{\mathrm{b}}$ & 41.7 & 1.2 & 4.1 & 26.2 & 2.7
\end{tabular}

a Reaction conditions: $\mathrm{C}_{15} \mathrm{H}_{31} \mathrm{COOC}_{16} \mathrm{H}_{33}: 5$ g; catalyst: 0.2 g; $\mathrm{N}_{2}$ pressure at $25^{\circ} \mathrm{C}: 0.9 \mathrm{MPa} .{ }^{\mathrm{b}}$ Pd loading: 1 wt. $\%$.

Figure 8 shows the FID-GC charts of the liquid product formed by deoxygenation of $\mathrm{C}_{15} \mathrm{H}_{31} \mathrm{COOC}_{16} \mathrm{H}_{33}$ in $\mathrm{N}_{2}$ atmosphere at $300^{\circ} \mathrm{C}$ for $2 \mathrm{~h}$ over $1 \mathrm{wt} . \% \mathrm{Pd} / \mathrm{Mg}(\mathrm{Al}) \mathrm{O}$ catalyst. A comparison of Figures $5 \mathrm{~B}$ and $8 \mathrm{~A}$ shows that the peak of the $\mathrm{C}_{15} \mathrm{H}_{31} \mathrm{COOC}_{16} \mathrm{H}_{33}$ reactant still appears in the GC chart after reaction in $\mathrm{N}_{2}$ atmosphere. For the deoxygenation of $\mathrm{C}_{15} \mathrm{H}_{31} \mathrm{COOC}_{16} \mathrm{H}_{33}$ over the $\mathrm{Pd} / \mathrm{Mg}(\mathrm{Al}) \mathrm{O}$ catalyst, the reaction rate in $\mathrm{N}_{2}$ atmosphere was slow in comparison with that in the $\mathrm{H}_{2}$ atmosphere. The reaction in $\mathrm{N}_{2}$ atmosphere formed some compounds with a retention time ranging from 14 to $22 \mathrm{~min}$ in the GC chart (fatty acid, alcohol, and ketones). These compounds decreased the yield of hydrocarbons from the deoxygenation of $\mathrm{C}_{15} \mathrm{H}_{31} \mathrm{COOC}_{16} \mathrm{H}_{33}$. Moreover, peaks of $\mathrm{C}_{5}-\mathrm{C}_{14}$ hydrocarbons appear in the GC chart of the $2 \mathrm{~h}$ reaction in $\mathrm{N}_{2}$ atmosphere (Figure 8A). Figure $8 \mathrm{~B}$ shows the magnified area from 11.1 to $14.1 \mathrm{~min}$ in Figure 8A; this enables us to observe the composition of $\mathrm{C}_{15}$ and $\mathrm{C}_{16}$ hydrocarbons that are formed by the reaction in $\mathrm{N}_{2}$ atmosphere. As shown in Figure $5 \mathrm{~B}$, deoxygenation of $\mathrm{C}_{15} \mathrm{H}_{31} \mathrm{COOC}_{16} \mathrm{H}_{33}$ in $\mathrm{H}_{2}$ atmosphere only formed normal paraffin hydrocarbons. As shown in Figure 8B, the hydrocarbon products that are formed by the deoxygenation of $\mathrm{C}_{15} \mathrm{H}_{31} \mathrm{COOC}_{16} \mathrm{H}_{33}$ in $\mathrm{N}_{2}$ atmosphere contained $n$-paraffin and several kinds of olefins. A comparison of the GC-MS results with values in the NIST-11 database indicates that the peaks around n-paraffin were olefins with the same number of carbon chains. The initially formed olefins were converted into other olefins by double bond migration on the basic sites of $\mathrm{Mg}(\mathrm{Al}) \mathrm{O}$. Solid base catalysts (such as $\mathrm{MgO}$ ) have the catalytic ability for double bond migration of olefins [43]. By calculating the amount of each component in the product using the GC chart, the amount of total $\mathrm{C}_{16}$ hydrocarbons and the amount of total $\mathrm{C}_{15}$ hydrocarbons was found to be almost the same in the liquid product that was formed from the catalytic deoxygenation of $\mathrm{C}_{15} \mathrm{H}_{31} \mathrm{COOC}_{16} \mathrm{H}_{33}$ in $\mathrm{N}_{2}$ atmosphere, at $300^{\circ} \mathrm{C}$, for $2 \mathrm{~h}$, over the $\mathrm{Pd} / \mathrm{Mg}(\mathrm{Al}) \mathrm{O}$ catalyst. 

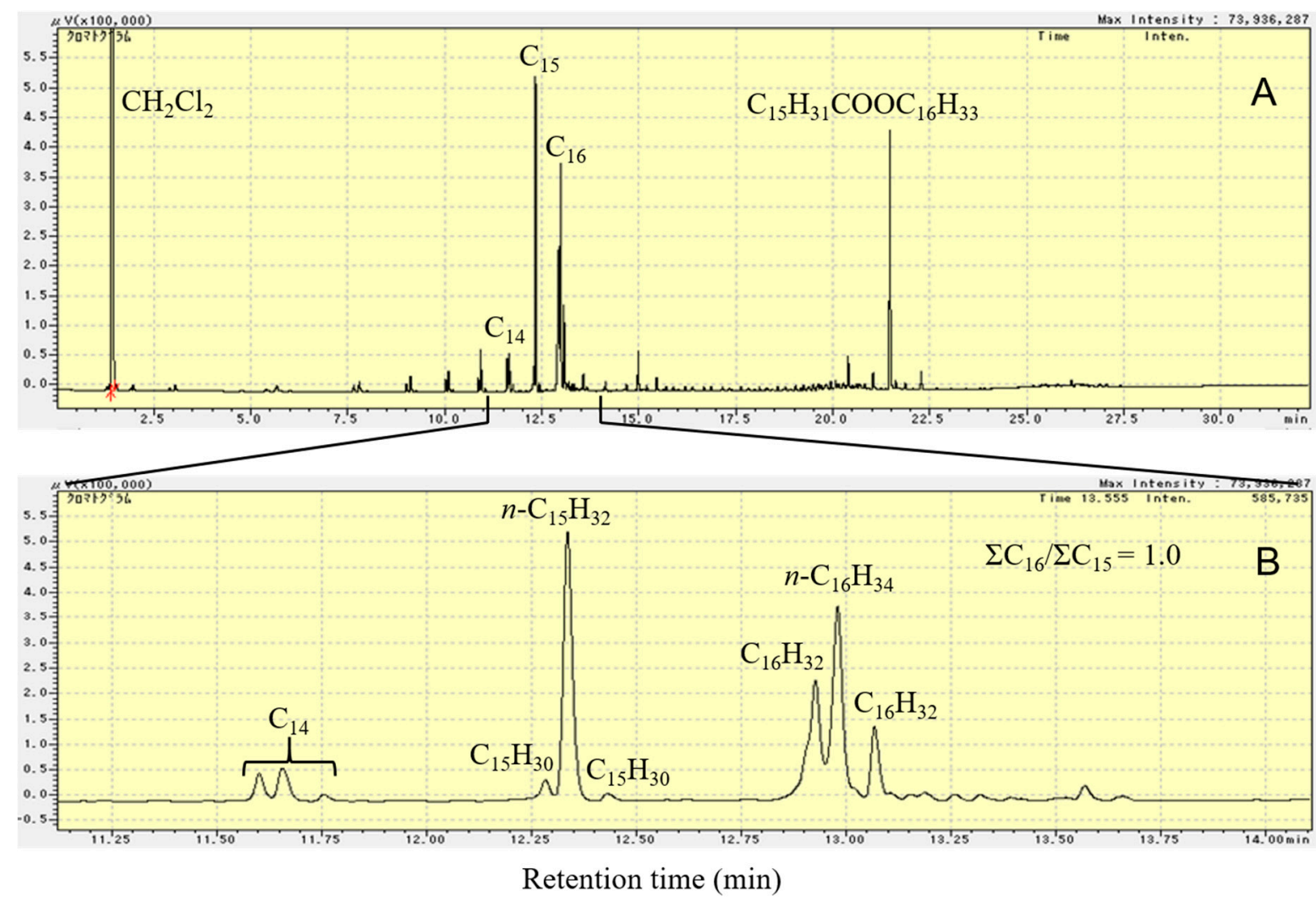

Figure 8. The FID-GC charts of the liquid product formed by deoxygenation of $\mathrm{C}_{15} \mathrm{H}_{31} \mathrm{COOC}_{16} \mathrm{H}_{33}$ in $\mathrm{N}_{2}$ atmosphere at $300{ }^{\circ} \mathrm{C}$ for $2 \mathrm{~h}$ over $1 \mathrm{wt} . \% \mathrm{Pd} / \mathrm{Mg}(\mathrm{Al}) \mathrm{O}$ catalyst. (A): retention time from 0 to $32 \mathrm{~min},(\mathbf{B})$ : retention time from 11.1 to $14.1 \mathrm{~min}$. Reaction conditions: $\mathrm{C}_{15} \mathrm{H}_{31} \mathrm{COOC}_{16} \mathrm{H}_{33}$ : 5 g; catalyst: $0.2 \mathrm{~g} ; \mathrm{N}_{2}$ pressure at $25^{\circ} \mathrm{C}: 0.9 \mathrm{MPa}$.

Reactions (7) and (8) show the reactions for the deoxygenation of $\mathrm{C}_{15} \mathrm{H}_{31} \mathrm{COOC}_{16} \mathrm{H}_{33}$ in $\mathrm{N}_{2}$ (without $\mathrm{H}_{2}$ ) atmosphere. $\mathrm{CO}$ could not be detected in the gas products of the reaction in $\mathrm{N}_{2}$ atmosphere, thus, decarboxylation was deduced to be the only reaction in the deoxygenation of $\mathrm{C}_{15} \mathrm{H}_{31} \mathrm{COOC}_{16} \mathrm{H}_{33}$ in $\mathrm{N}_{2}$ atmosphere.

$$
\begin{aligned}
& \mathrm{C}_{15} \mathrm{H}_{31} \mathrm{COOC}_{16} \mathrm{H}_{33}=\mathrm{C}_{15} \mathrm{H}_{32}+\mathrm{C}_{16} \mathrm{H}_{32}+\mathrm{CO}_{2} \text { Decarboxylation } \\
& \mathrm{C}_{15} \mathrm{H}_{31} \mathrm{COOC}_{16} \mathrm{H}_{33}=\mathrm{C}_{15} \mathrm{H}_{30}+\mathrm{C}_{16} \mathrm{H}_{34}+\mathrm{CO}_{2} \text { Decarboxylation }
\end{aligned}
$$

In $\mathrm{N}_{2}$ atmosphere, the number of $\mathrm{H}$ atoms in the $\mathrm{C}_{15} \mathrm{H}_{31} \mathrm{COOC}_{16} \mathrm{H}_{33}$ molecule was not enough to obtain the saturated hydrocarbons $\mathrm{C}_{16} \mathrm{H}_{34}$ and $\mathrm{C}_{15} \mathrm{H}_{32}$ in the decarboxylation of $\mathrm{C}_{15} \mathrm{H}_{31} \mathrm{COOC}_{16} \mathrm{H}_{33}$. One $\mathrm{C}_{15} \mathrm{H}_{31} \mathrm{COOC}_{16} \mathrm{H}_{33}$ molecule must form one paraffin and one olefin by decarboxylation without $\mathrm{H}_{2}$. The high reactivity of the olefin molecules formed resulted in the formation of light hydrocarbons. A few heavy hydrocarbons larger than $C_{16}$ were also formed by the polymerization of light olefins. Because both Reactions (7) and (8) form the same amount of $C_{15}$ and $C_{16}$ hydrocarbons, the molar ratio of total $C_{16}$ hydrocarbons to total $C_{15}$ hydrocarbons was 1.0, as shown in Figure 8B. Moreover, the ratio of $n-\mathrm{C}_{15} \mathrm{H}_{32}$ in the total $\mathrm{C}_{15}$ hydrocarbons was much higher than the ratio of $n-\mathrm{C}_{16} \mathrm{H}_{34}$ in the total $\mathrm{C}_{16}$ hydrocarbons (Figure 8B). Thus, Reaction (7) was the main decarboxylation reaction (as compared to Reaction (8)) in the catalytic deoxygenation of $\mathrm{C}_{15} \mathrm{H}_{31} \mathrm{COOC}_{16} \mathrm{H}_{33}$ in $\mathrm{N}_{2}$ atmosphere.

For deoxygenation of $\mathrm{C}_{15} \mathrm{H}_{31} \mathrm{COOC}_{16} \mathrm{H}_{33}$ in $\mathrm{N}_{2}$ atmosphere, the metal site alone could not achieve enough activity, because deoxygenation was carried out via a single route, namely decarboxylation. In this study, we used a base support $(\mathrm{Mg}(\mathrm{Al}) \mathrm{O})$ for the metal $(\mathrm{Pd})$ in order to enhance the catalytic activity during deoxygenation of $\mathrm{C}_{15} \mathrm{H}_{31} \mathrm{COOC}_{16} \mathrm{H}_{33}$ in $\mathrm{N}_{2}$ atmosphere. 
Figure 9 shows the dependence of $\mathrm{C}_{15} \mathrm{H}_{31} \mathrm{COOC}_{16} \mathrm{H}_{33}$ conversion and $\mathrm{C}_{10}-\mathrm{C}_{16}$ hydrocarbons yield on reaction time for the catalytic deoxygenation of $\mathrm{C}_{15} \mathrm{H}_{31} \mathrm{COOC}_{16} \mathrm{H}_{33}$ in $\mathrm{N}_{2}$ atmosphere, at $300{ }^{\circ} \mathrm{C}$, over the $1 \mathrm{wt} . \% \mathrm{Pd} / \mathrm{Mg}(\mathrm{Al}) \mathrm{O}$ catalyst. $\mathrm{C}_{15} \mathrm{H}_{31} \mathrm{COOC}_{16} \mathrm{H}_{33}$ conversion increased with prolonged reaction time and reached $100 \%$ after reaction for $6 \mathrm{~h}$. The yield of $\mathrm{C}_{10}-\mathrm{C}_{16}$ hydrocarbons increased with prolonged reaction until $5 \mathrm{~h}$, and then decreased slightly due to the formation of light hydrocarbons. Although the catalytic activity in $\mathrm{N}_{2}$ atmosphere was lower than that in the $\mathrm{H}_{2}$ atmosphere, the $\mathrm{Pd} / \mathrm{Mg}(\mathrm{Al}) \mathrm{O}$ catalyst yielded a $\mathrm{C}_{15} \mathrm{H}_{31} \mathrm{COOC}_{16} \mathrm{H}_{33}$ conversion of $99.1 \%$ and a $\mathrm{C}_{10}-\mathrm{C}_{16}$ hydrocarbon yield of $80.4 \%$ by prolonging reaction time to $5 \mathrm{~h}$ for the reaction in $\mathrm{N}_{2}$ atmosphere at $300{ }^{\circ} \mathrm{C}$.

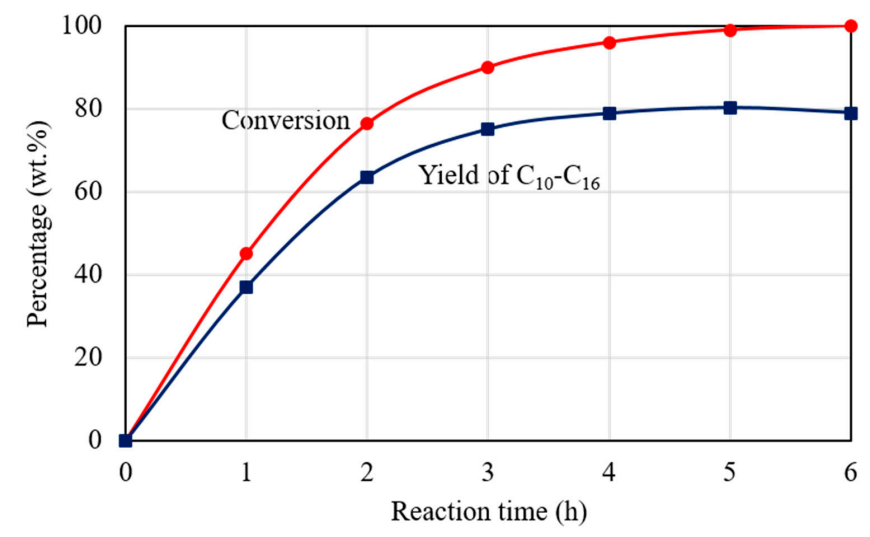

Figure 9. The dependence of $\mathrm{C}_{15} \mathrm{H}_{31} \mathrm{COOC}_{16} \mathrm{H}_{33}$ conversion and $\mathrm{C}_{10}-\mathrm{C}_{16}$ hydrocarbons yield on reaction time for the catalytic deoxygenation of $\mathrm{C}_{15} \mathrm{H}_{31} \mathrm{COOC}_{16} \mathrm{H}_{33}$ in $\mathrm{N}_{2}$ atmosphere, at $300{ }^{\circ} \mathrm{C}$, over the 1 wt. $\% \mathrm{Pd} / \mathrm{Mg}(\mathrm{Al}) \mathrm{O}$ catalyst. Reaction conditions: $\mathrm{C}_{15} \mathrm{H}_{31} \mathrm{COOC}_{16} \mathrm{H}_{33}: 5$ g; catalyst: 0.2 g; $\mathrm{N}_{2}$ pressure at $25^{\circ} \mathrm{C}: 0.9 \mathrm{MPa}$.

Figure 10 shows the dependence of $\mathrm{C}_{15} \mathrm{H}_{31} \mathrm{COOC}_{16} \mathrm{H}_{33}$ conversion and $\mathrm{C}_{10}-\mathrm{C}_{16}$ hydrocarbon yield on reaction temperature for the catalytic deoxygenation of $\mathrm{C}_{15} \mathrm{H}_{31} \mathrm{COOC}_{16} \mathrm{H}_{33}$ in $\mathrm{N}_{2}$ atmosphere, for $2 \mathrm{~h}$, over the $1 \mathrm{wt} . \% \mathrm{Pd} / \mathrm{Mg}(\mathrm{Al}) \mathrm{O}$ catalyst. $\mathrm{C}_{15} \mathrm{H}_{31} \mathrm{COOC}_{16} \mathrm{H}_{33}$ conversion increased with an increasing reaction temperature from 275 to $375{ }^{\circ} \mathrm{C}$, and achieved a conversion of over $99 \%$ for the reaction at $375^{\circ} \mathrm{C}$ for $2 \mathrm{~h}$. The yield of $\mathrm{C}_{10}-\mathrm{C}_{16}$ hydrocarbons increased with an increasing reaction temperature from 275 to $325^{\circ} \mathrm{C}$. At a reaction temperature higher than $325^{\circ} \mathrm{C}$, the yield of $\mathrm{C}_{10}-\mathrm{C}_{16}$ hydrocarbons could not be improved by increasing the reaction temperature because the number of light hydrocarbons $\left(<\mathrm{C}_{9}\right)$ in the product increased at high reaction temperatures.

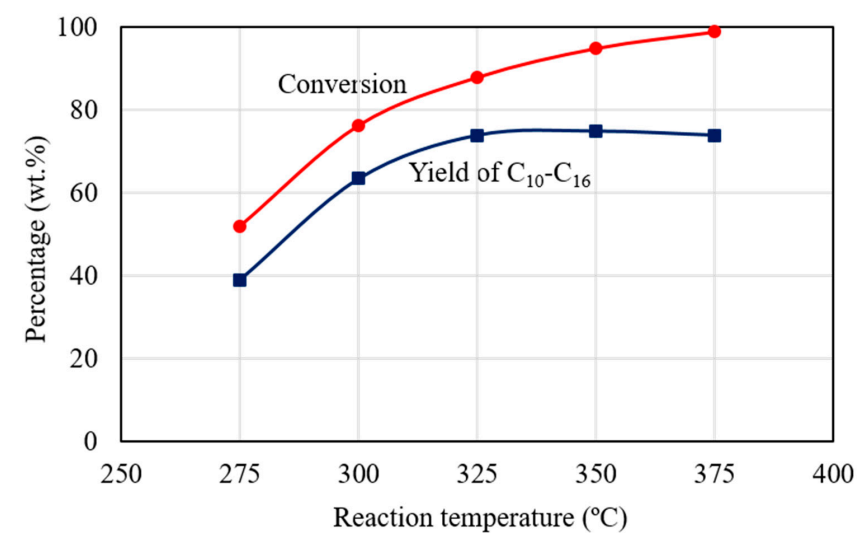

Figure 10. The dependence of $\mathrm{C}_{15} \mathrm{H}_{31} \mathrm{COOC}_{16} \mathrm{H}_{33}$ conversion and $\mathrm{C}_{10}-\mathrm{C}_{16}$ hydrocarbon yield on reaction temperature for the catalytic deoxygenation of $\mathrm{C}_{15} \mathrm{H}_{31} \mathrm{COOC}_{16} \mathrm{H}_{33}$ in $\mathrm{N}_{2}$ atmosphere, for $2 \mathrm{~h}$, over the 1 wt.\% Pd/Mg(Al)O catalyst. Reaction conditions: $\mathrm{C}_{15} \mathrm{H}_{31} \mathrm{COOC}_{16} \mathrm{H}_{33}: 5$ g; catalyst: 0.2 g; $\mathrm{N}_{2}$ pressure at $25^{\circ} \mathrm{C}: 0.9 \mathrm{MPa}$. 


\section{Experimental Section}

\subsection{Reagents}

Hexadecyl palmitate $\left(\mathrm{C}_{15} \mathrm{H}_{31} \mathrm{COOC}_{16} \mathrm{H}_{33}\right)$ of purity higher than $95 \%$ was purchased from Tokyo Chemical Industry Co., Ltd. (Tokyo, Japan) Na-ZSM-5 zeolite $\left(\mathrm{SiO}_{2} / \mathrm{Al}_{2} \mathrm{O}_{3}=50\right.$ ) was purchased from Wako Pure Chemical Industries, Ltd. (Tokyo, Japan) Activated carbon (C), with a particle size of 100 mesh, was purchased from Aldrich Chem. Co. Inc. (Milwaukee, WI, USA); the BET surface area of the $C$ support was $593 \mathrm{~m}^{2} / \mathrm{g}$ by $\mathrm{N}_{2}$ adsorption measurement. Other chemical reagents were purchased from Wako Pure Chemical Industries Ltd. (Tokyo, Japan) with purities higher than 99\%. Gas cylinders were purchased from Sumitomo Seika Chemicals Co., Ltd. (Tokyo, Japan) with purities higher than $99.995 \%$.

\subsection{Catalysts}

$\mathrm{Pd}_{0.016} \mathrm{Mg}_{3} \mathrm{Al}(\mathrm{OH})_{16} \mathrm{CO}_{3} \cdot x \mathrm{H}_{2} \mathrm{O}$ hydrotalcite was prepared using a co-precipitation method at $\mathrm{pH} 10.0$, by adding an aqueous solution containing $\mathrm{Pd}\left(\mathrm{NO}_{3}\right)_{2}, \mathrm{Mg}\left(\mathrm{NO}_{3}\right)_{2}$, and $\mathrm{Al}\left(\mathrm{NO}_{3}\right)_{3}$ (the molar ratio of $\mathrm{Pd}$ to $\mathrm{Mg}$ to $\mathrm{Al}$ was 0.016:3:1) to a solution containing a slight excess of $\mathrm{Na}_{2} \mathrm{CO}_{3}$ at $65{ }^{\circ} \mathrm{C}$. A $1 \mathrm{M} \mathrm{NaOH}$ aqueous solution was added during the process to maintain the $\mathrm{pH}$ value at 10.0. After standing at $65^{\circ} \mathrm{C}$ for $4 \mathrm{~h}$, a precipitate was obtained by filtration. The resultant precipitate was dried in air at $100{ }^{\circ} \mathrm{C}$ for $24 \mathrm{~h}$.

The $\mathrm{Pd} / \mathrm{Mg}(\mathrm{Al}) \mathrm{O}$ catalyst was obtained by reducing $\mathrm{PdO}-\mathrm{Mg}(\mathrm{Al}) \mathrm{O}$ mixed oxide under $\mathrm{H}_{2}$ flow $(60 \mathrm{~mL} / \mathrm{min})$ at $300{ }^{\circ} \mathrm{C}$ for $1 \mathrm{~h}$. The $\mathrm{PdO}-\mathrm{Mg}(\mathrm{Al}) \mathrm{O}$ mixed oxide was obtained by calcining $\mathrm{Pd}_{0.016} \mathrm{Mg}_{3} \mathrm{Al}(\mathrm{OH})_{16} \mathrm{CO}_{3} \cdot x \mathrm{H}_{2} \mathrm{O}$ hydrotalcite in air at $450{ }^{\circ} \mathrm{C}$ for $3 \mathrm{~h}$. By calculating the amount of $\mathrm{Pd}$ in the $\mathrm{Pd}_{0.016} \mathrm{Mg}_{3} \mathrm{Al}(\mathrm{OH})_{16} \mathrm{CO}_{3} \cdot 4 \mathrm{H}_{2} \mathrm{O}$ precursor, the designed Pd loading was determined to be about $1 \mathrm{wt} . \%$ in the $\mathrm{Pd} / \mathrm{Mg}(\mathrm{Al}) \mathrm{O}$ catalyst. The actual amount of $\mathrm{Pd}$ loading (measured by elemental analysis) was $0.95 \mathrm{wt} . \%$ in the $\mathrm{Pd} / \mathrm{Mg}(\mathrm{Al}) \mathrm{O}$ catalyst.

$\mathrm{Mg}(\mathrm{Al}) \mathrm{O}$ was obtained by calcination of $\mathrm{Mg}_{3} \mathrm{Al}(\mathrm{OH})_{16} \mathrm{CO}_{3} \cdot x \mathrm{H}_{2} \mathrm{O}$ hydrotalcite in air at $450{ }^{\circ} \mathrm{C}$ for $3 \mathrm{~h} . \mathrm{Mg}_{3} \mathrm{Al}(\mathrm{OH})_{16} \mathrm{CO}_{3} \cdot x \mathrm{H}_{2} \mathrm{O}$ hydrotalcite was prepared by a co-precipitation method at $\mathrm{pH}$ 10.0, by adding an aqueous solution containing $\mathrm{Mg}\left(\mathrm{NO}_{3}\right)_{2}$ and $\mathrm{Al}\left(\mathrm{NO}_{3}\right)_{3}$ (molar ratio of $\mathrm{Mg}$ to $\mathrm{Al}$ was 3) to a solution containing a slight excess of $\mathrm{Na}_{2} \mathrm{CO}_{3}$ at $65{ }^{\circ} \mathrm{C}$. A $1 \mathrm{M} \mathrm{NaOH}$ aqueous solution was added during the process to maintain the $\mathrm{pH}$ value at 10.0 . The resultant precipitate was washed and dried in air at $100^{\circ} \mathrm{C}$ for $24 \mathrm{~h}$.

H-ZSM- 5 was prepared using Na-ZSM- 5 as follows. Na-ZSM- 5 was treated with an aqueous solution of $\mathrm{NH}_{4} \mathrm{NO}_{3}(0.1 \mathrm{M})$ to form $\mathrm{NH}_{4}-\mathrm{ZSM}-5$ by ion exchange. After filtering out the water, the $\mathrm{NH}_{4}$-ZSM-5 obtained was dried in air at $100{ }^{\circ} \mathrm{C}$ for $24 \mathrm{~h}$, and then calcined in air at $550{ }^{\circ} \mathrm{C}$ for $3 \mathrm{~h}$ to form H-ZSM-5.

$\mathrm{Pd} / \mathrm{C}$ was synthesized by using a wet impregnation method. The activated carbon support was impregnated with an aqueous solution of $\mathrm{Pd}\left(\mathrm{NO}_{3}\right)_{2}$ with stirring. After removal of the solvent by heating at $90{ }^{\circ} \mathrm{C}$, the resultant solid product was dried in air at $100{ }^{\circ} \mathrm{C}$ for $24 \mathrm{~h}$. Then, $\mathrm{Pd} / \mathrm{C}$ was calcined under a $\mathrm{N}_{2}$ flow $(60 \mathrm{~mL} / \mathrm{min})$ at $400{ }^{\circ} \mathrm{C}$ for $1 \mathrm{~h}$ to remove $\mathrm{NO}_{3}{ }^{-}$ions. In the $\mathrm{Pd} / \mathrm{C}$ catalyst, the designed Pd loading was $1 \mathrm{wt} . \%$ and the actual amount of Pd loading (measured by element analysis) was $1.02 \mathrm{wt} . \%$.

\subsection{Instruments}

Powder X-ray diffraction (XRD) patterns were measured using a MAC Science MXP-18 diffractometer (XrayScience Corp., Tokyo, Japan) with $\mathrm{Cu} \mathrm{K \alpha}$ radiation operated at $40 \mathrm{kV}$ and $50 \mathrm{~mA}$. The solid phase was identified by referring to the JICST database (Version 6th, Japan Information Center of Science and Technology, Tokyo, Japan, 2012) from The Crystallographic Society of Japan. Thermogravimetric and differential thermal analyses (TG-DTA) were carried out using a Shimadzu TGA-50 instrument (Shimadzu Corp., Kyoto, Japan). The sample was heated under an atmosphere of $\mathrm{N}_{2}$ flow $(60 \mathrm{~mL} / \mathrm{min})$ at a heating rate of $5{ }^{\circ} \mathrm{C} / \mathrm{min}$ from room temperature to 
$1000{ }^{\circ} \mathrm{C} . \mathrm{N}_{2}$ adsorption measurements were carried out at $-196^{\circ} \mathrm{C}$ using a Belsorp 28SA automatic adsorption instrument (MicrotracBEL Corp., Osaka, Japan). The surface areas of the samples were obtained from a Brunauer-Emmett-Teller (BET) plot. Elemental analysis of Pd was measured by an inductive coupled plasma analysis, using a Thermo Jarrell Ash IRIS/AP instrument (SpectraLab Scientific Inc., Markham, ON, Canada).

\subsection{Reactions}

Before reaction, $\mathrm{Pd} / \mathrm{Mg}(\mathrm{Al}) \mathrm{O}$ and $\mathrm{Pd} / \mathrm{C}$ were reduced in a $\mathrm{H}_{2}$ flow $(60 \mathrm{~mL} / \mathrm{min})$ at $300{ }^{\circ} \mathrm{C}$ for $1 \mathrm{~h}$. The reaction was carried out in a type of $100-\mathrm{mL}$ stainless-steel autoclave reactor with a stirrer. In general, $0.2 \mathrm{~g}$ catalyst and $5 \mathrm{~g}$ hexadecyl palmitate $\left(\mathrm{C}_{15} \mathrm{H}_{31} \mathrm{COOC}_{16} \mathrm{H}_{33}\right)$ were introduced into an autoclave reactor. Then, $0.9 \mathrm{MPa} \mathrm{H}_{2}$ (for the reaction in $\mathrm{H}_{2}$ atmosphere) or $0.9 \mathrm{MPa} \mathrm{N}$ (for the reaction in $\mathrm{N}_{2}$ atmosphere) was charged into the autoclave at room temperature $\left(25^{\circ} \mathrm{C}\right)$. The autoclave reactor was then heated and was kept at the reaction temperature $\left(275-375^{\circ} \mathrm{C}\right)$ for $1-6 \mathrm{~h}$ with vigorous stirring $(600 \mathrm{rpm})$. After the reaction, the reactor was cooled down to room temperature before analysis.

\subsection{Analyses}

The gas products were collected into a plastic bag, from which the air had been taken out by using a pump. The total volume of the total gas was measured using a WS- 1 integration flow meter (Shinagawa Corp., Tokyo, Japan). The composition of the gas products was analysed using gas chromatography (Shimadzu Corp., Kyoto, Japan). Inorganic gases $\left(\mathrm{H}_{2}, \mathrm{~N}_{2}, \mathrm{CO}\right.$, and $\mathrm{CO}_{2}$ ) were analysed using a Shimadzu 14B type GC with a thermal conductivity detector (TCD) that was equipped with MS-5A and Porapak-Q columns. Gaseous hydrocarbons $\left(C_{1}-C_{4}\right)$ were analysed using a Shimadzu GC-2014 type FID-GC equipped with an RT-QPLOT (Agilent Technologies Japan, Ltd, Tokyo, Japan) capillary column. The factors of various gases $\left(\mathrm{H}_{2}, \mathrm{~N}_{2}, \mathrm{CO}, \mathrm{CO}_{2}, \mathrm{C}_{1}-\mathrm{C}_{4}\right.$ hydrocarbons) were obtained using a standard mixed gas (with known concentration for each component) from a cylinder.

The liquid products were taken out from the autoclave reactor. After filtering out the solid catalyst, a certain amount of dioxane $\left(\mathrm{C}_{4} \mathrm{H}_{8} \mathrm{O}_{2}\right)$ was added to the liquid products as an internal standard. Dichloromethane $\left(\mathrm{CH}_{2} \mathrm{Cl}_{2}\right)$ was used as a solvent to wash the reactor and the used catalyst, and then mixed with the liquid products. The liquid products were analysed by a Shimadzu GC-2014 type GC-FID equipped with a UA-DX30 capillary column (Frontier Laboratories Ltd., Koriyama, Fukushima, Japan). Gas chromatography-mass spectrometry (GC-MS) analysis was performed on a Shimadzu GCMS-QP2010 Ultra (Shimadzu Corp., Kyoto, Japan) to confirm the components of the liquid products. Each component in the liquid product was separated on a UA-DX30 capillary column, and was identified by GC-MS analysis, with reference to the NIST-11 database. The amount of each normal paraffin in the product was calculated from the results of GC-FID analysis, and the factor of each normal paraffin was obtained using a pure reagent with a certain amount of dioxane $\left(\mathrm{C}_{4} \mathrm{H}_{8} \mathrm{O}_{2}\right)$ in the GC-FID analysis. Each olefin in the product was identified by GC-MS analysis, and the amount of each olefin was calculated from the results of GC-FID analysis by using the factor of a normal paraffin with the same number of carbon chains.

Using the results of the $\mathrm{GC}$ analyses, $\mathrm{C}_{15} \mathrm{H}_{31} \mathrm{COOC}_{16} \mathrm{H}_{33}$ conversion was calculated from the ratio of the decreased amount to the fed amount of $\mathrm{C}_{15} \mathrm{H}_{31} \mathrm{COOC}_{16} \mathrm{H}_{33}$; the yield of each carbon-containing product was calculated from the ratio of the formed amount of each product to the fed amount of $\mathrm{C}_{15} \mathrm{H}_{31} \mathrm{COOC}_{16} \mathrm{H}_{33}$. The carbon mass balance (before and after reaction) had an error less than $\pm 5 \%$ for the reaction in $\mathrm{H}_{2}$ atmosphere, and had an error less than $\pm 10 \%$ for the reaction in $\mathrm{N}_{2}$ atmosphere.

\section{Conclusions}

The $\mathrm{Pd} / \mathrm{Mg}(\mathrm{Al}) \mathrm{O}$ catalyst derived from $\mathrm{Pd}_{0.016} \mathrm{Mg}_{3} \mathrm{Al}(\mathrm{OH})_{16} \mathrm{CO}_{3} \cdot x \mathrm{H}_{2} \mathrm{O}$ hydrotalcite precursor showed a high catalytic performance in both $\mathrm{H}_{2}$ and $\mathrm{N}_{2}$ atmospheres for the catalytic deoxygenation of $\mathrm{C}_{15} \mathrm{H}_{31} \mathrm{COOC}_{16} \mathrm{H}_{33}$. In $\mathrm{H}_{2}$ atmosphere, the reduction of $\mathrm{C}_{15} \mathrm{H}_{31} \mathrm{COOC}_{16} \mathrm{H}_{33}$ was the main reaction, and the main products were $\mathrm{n}-\mathrm{C}_{16} \mathrm{H}_{34}$ and $\mathrm{n}-\mathrm{C}_{15} \mathrm{H}_{32}$ from the deoxygenation of $\mathrm{C}_{15} \mathrm{H}_{31} \mathrm{COOC}_{16} \mathrm{H}_{33}$ 
over Pd/Mg(Al)O. In $\mathrm{N}_{2}$ atmosphere, the decarboxylation of $\mathrm{C}_{15} \mathrm{H}_{31} \mathrm{COOC}_{16} \mathrm{H}_{33}$ was the main reaction, and olefins and paraffins were formed as the products of deoxygenation of $\mathrm{C}_{15} \mathrm{H}_{31} \mathrm{COOC}_{16} \mathrm{H}_{33}$ over $\mathrm{Pd} / \mathrm{Mg}(\mathrm{Al}) \mathrm{O}$. The catalytic reaction in $\mathrm{N}_{2}$ atmosphere was slower than that in $\mathrm{H}_{2}$ atmosphere over $\mathrm{Pd} / \mathrm{Mg}(\mathrm{Al}) \mathrm{O} . \mathrm{Pd} / \mathrm{Mg}(\mathrm{Al}) \mathrm{O}$ showed a much higher catalytic performance than that reported for other catalysts for the deoxygenation of $\mathrm{C}_{15} \mathrm{H}_{31} \mathrm{COOC}_{16} \mathrm{H}_{33}$ in $\mathrm{N}_{2}$ atmosphere. Prolonging the reaction time or increasing the reaction temperature improved the yield of $\mathrm{C}_{10}-\mathrm{C}_{16}$ hydrocarbons until the $\mathrm{C}_{15} \mathrm{H}_{31} \mathrm{COOC}_{16} \mathrm{H}_{33}$ conversion approached $100 \%$ for the reaction in $\mathrm{N}_{2}$ atmosphere over the $\mathrm{Pd} / \mathrm{Mg}(\mathrm{Al}) \mathrm{O}$ catalyst.

Author Contributions: The author Y.L. conceived and designed the experiments, Y.L. performed the experiments, Y.L, M.I., and K.M. analyzed the data, Y.L. drafted the paper. All authors have given approval for the final version of the manuscript.

Conflicts of Interest: The authors declare no conflict of interest.

\section{References}

1. Cesaro, A.; Belgiorno, V. Combined biogas and bioethanol production: Opportunities and challenge for industrial application. Energies 2015, 8, 8121-8144. [CrossRef]

2. Hanaoka, T.; Liu, Y.; Matsunaga, K.; Miyazawa, T.; Hirata, S.; Sakanishi, K. Bench-scale production of liquid fuel from woody biomass via gasification. Fuel Process. Technol. 2010, 91, 859-865. [CrossRef]

3. Liu, Y.; Hanaoka, T.; Miyazawa, T.; Murata, K.; Okabe, K.; Sakanishi, K. Fischer-Tropsch synthesis in slurry-phase reactors over Mn- and $\mathrm{Zr}$-modified $\mathrm{Co} / \mathrm{SiO}_{2}$ catalysts. Fuel Process. Technol. 2009, 90, 901-908. [CrossRef]

4. Thanh, L.T.; Okitsu, K.; Boi, L.V.; Maeda, Y. Catalytic technologies for biodiesel fuel production and utilization of glycerol: A review. Catalysts 2012, 2, 191-222. [CrossRef]

5. Zhao, X.; Wei, L.; Cheng, S.; Julson, J. Review of heterogeneous catalysts for catalytically upgrading vegetable oils into hydrocarbon biofuels. Catalysts 2017, 7, 83. [CrossRef]

6. Liu, Y.; Sotelo-Boyas, R.; Murata, K.; Minowa, T.; Sakanishi, K. Production of bio-hydrogenated diesel by hydrotreatment of high-acid-value waste cooking oil over ruthenium catalyst supported on Al-polyoxocation-pillared pontmorillonite. Catalysts 2012, 2, 171-190. [CrossRef]

7. Liu, Y.; Sotelo-Boyas, R.; Murata, K.; Minowa, T.; Sakanishi, K. Hydrotreatment of vegetable oils to produce bio-hydrogenated diesel and liquefied petroleum gas fuel over catalysts containing sulfided Ni-Mo and solid Acids. Energy Fuels 2011, 25, 4675-4685. [CrossRef]

8. Yoshida, M.; Tanabe, Y.; Yonezawa, N.; Watanabe, M.M. Energy innovation potential of oleaginous microalgae. Biofuels 2012, 3, 761-781. [CrossRef]

9. Georgianna, D.R.; Mayfield, S.P. Exploiting diversity and synthetic biology for the production of algal biofuels. Nature 2012, 488, 329-335. [CrossRef] [PubMed]

10. Chisti, Y. Biodiesel from microalgae. Biotechnol. Adv. 2007, 25, 294-306. [CrossRef] [PubMed]

11. Milledge, J.J.; Smith, B.; Dyer, P.W.; Harvey, P. Macroalgae-derived biofuel: A review of method of energy extraction from seaweed biomass. Energies 2014, 7, 7194-7222. [CrossRef]

12. Kanda, H.; Li, P.; Goto, M.; Makio, H. Energy-saving lipid extraction from wet Euglena gracilis by the low-boiling-point solvent dimethyl ether. Energies 2015, 8, 610-620. [CrossRef]

13. Tani, Y.; Okumura, M.; Ii, S. Liquid wax ester production by euglena gracilis. Agric. Biol. Chem. 1987, 51, 225-230. [CrossRef]

14. Maki-Arvela, P.; Kubickova, I.; Snare, M.; Eranen, K.; Murzin, D.Y. Catalytic deoxygenation of fatty acids and their derivatives. Energy Fuels 2007, 21, 30-41. [CrossRef]

15. Sotelo-Boyas, R.; Liu, Y.; Minowa, T. Renewable diesel production from the hydrotreating of rapeseed oil with $\mathrm{Pt} / \mathrm{Zeolite}$ and $\mathrm{NiMo} / \mathrm{Al}_{2} \mathrm{O}_{3}$ catalysts. Ind. Eng. Chem. Res. 2011, 50, 2791-2799. [CrossRef]

16. Murata, K.; Liu, Y.; Watanabe, M.M.; Inaba, M.; Takahara, I. Hydrocracking of algae oil into aviation fuel-range hydrocarbons using a Pt-Re catalyst. Energy Fuels 2014, 28, 6999-7006. [CrossRef]

17. Sanchez-Cardenas, M.; Medina-Valtierra, J.; Kamaraj, S.-K.; Ramirez, R.R.M.; Sanchez-Olmos, L.A. Effect of size and distribution of Ni nanoparticles on $\gamma-\mathrm{Al}_{2} \mathrm{O}_{3}$ in oleic acid hydrodeoxygenation to produce $n$-alkanes. Catalysts 2016, 6, 156. [CrossRef] 
18. Charusiri, W.; Vitidsant, T. Catalytic cracking of used cooking oil to liquid fuels over HZSM-5. J. Energy 2003, 5, 58-68.

19. Na, J.G.; Han, J.K.; Oh, Y.K.; Park, J.H.; Jung, T.S.; Han, S.S.; Yoon, H.C.; Chung, S.H.; Kim, J.N.; Ko, C.H. Decarboxylation of microalgal oil without hydrogen into hydrocarbon for the production of transportation fuel. Catal. Today 2012, 185, 313-317. [CrossRef]

20. Tani, H.; Hasegawa, T.; Shimouchi, M.; Asami, K.; Fujimoto, K. Selective catalytic decarboxy-cracking of triglyceride to middle-distillate hydrocarbon. Catal. Today 2011, 164, 410-414. [CrossRef]

21. Maki-Arvela, P.; Rozmyszowicz, B.; Lestari, S.; Simakova, O.; Eranen, K.; Salmi, T.; Murzin, D.Y. Catalytic deoxygenation of Tall oil fatty acid over palladium supported on mesoporous carbon. Energy Fuels 2011, 25, 2815-2825. [CrossRef]

22. Cavani, F.; Trifiro, F.; Vaccari, A. Hydrotalcite-type anionic clays: Preparation, properties and applications. Catal. Today 1991, 11, 173-301. [CrossRef]

23. Basile, F.; Basini, L.; Fornasari, G.; Gazzano, M.; Trifiro, F.; Vaccari, A. New hydrotalcite-type anionic clays containing noble metals. Chem. Commun. 1996, 2435-2436. [CrossRef]

24. Narayanan, S.; Krishna, K. Structural influence of hydrotalcite on Pd dispersion and phenol hydrogenation. Chem. Commun. 1997, 1991-1992. [CrossRef]

25. Basile, F.; Fornasari, G.; Gazzano, M.; Vaccari, A. Synthesis and thermal evolution of hydrotalcite-type compounds containing noble metals. Appl. Clay Sci. 2000, 16, 185-200. [CrossRef]

26. Davis, R.J.; Derouane, E.G. A non-porous supported-platinum catalyst for aromatization of $n$-hexane. Nature 1991, 349, 313-315. [CrossRef]

27. Liu, Y.; Murata, K.; Hanaoka, T.; Inaba, M.; Sakanishi, K. Syntheses of new peroxo-polyoxometalates intercalated layered double hydroxides for propene epoxidation by molecular oxygen in methanol. J. Catal. 2007, 248, 277-287. [CrossRef]

28. Liu, Y.; Murata, K.; Inaba, M. Direct epoxidation of proptlene by molecular oxygen over catalyst system containing palladium and peroxo-Heteropoly compound in methanol. Chem. Commun. 2004, 582-583. [CrossRef] [PubMed]

29. Liu, Y.; Suzuki, K.; Hamakawa, S.; Hayakawa, T.; Murata, K.; Ishii, T.; Kumagai, M. Highly active methanol decomposition catalyst derived from Pd-hydrotalcite dispersed on mesoporous silica. Catal. Lett. 2000, 66, 205-213. [CrossRef]

30. Liu, Y.; Suzuki, K.; Hamakawa, S.; Hayakawa, T.; Murata, K.; Ishii, T.; Kumagai, M. Catalytic methanol decomposition at low temperature over Pd catalyst derived from mesoporous silica carried Pd-hydrotalcite. Chem. Lett. 2000, 486-487. [CrossRef]

31. Liu, Y.; Suzuki, K.; Hayakawa, T.; Tsunoda, T.; Suzuki, K.; Hamakawa, S.; Murata, K.; Shiozaki, R.; Ishii, T.; Kumagai, M. Steam reforming of methanol over $\mathrm{Cu} / \mathrm{CeO}_{2}$ catalysts studied in comparison with $\mathrm{Cu} / \mathrm{ZnO}$ and $\mathrm{Cu} / \mathrm{Zn}(\mathrm{Al}) \mathrm{O}$ catalysts. Top. Catal. 2003, 22, 205-213. [CrossRef]

32. Liu, Y.; Hayakawa, T.; Suzuki, K.; Hamakawa, S.; Tsunoda, T.; Ishii, T.; Kumagai, M. High active copper/ceria catalysts for the steam reforming of methanol. Appl. Catal. A Gen. 2002, 223, 137-145. [CrossRef]

33. Liu, Y.; Hayakawa, T.; Ishii, T.; Kumagai, M.; Yasuda, H.; Suzuki, K.; Hamakawa, S.; Murata, K. Methanol decomposition to synthesis gas at low temperature over palladium support on ceria-zirconia solid solutions. Appl. Catal. A Gen. 2001, 210, 301-314. [CrossRef]

34. Liu, Y.; Murata, K.; Inaba, M.; Takahara, I.; Okabe, K. Mixed synthesis of mixed alcohols from syngas over Cs- and Ni-modified $\mathrm{Cu} / \mathrm{CeO}_{2}$ catalysts. Fuel 2013, 104, 62-69. [CrossRef]

35. Liu, Y.; Murata, K.; Inaba, M.; Takahara, I.; Okabe, K. Synthesis of ethanol from syngas over Rh/Ce $1-x \mathrm{Zr}_{\mathrm{x}} \mathrm{O}_{2}$ catalysts. Catal. Today 2011, 164, 308-314. [CrossRef]

36. Liu, Y.; Murata, K.; Sakanishi, K. Hydroisomerization-cracking of gasoline distillate from Fischer-Tropsch synthesis over bifunctional catalysts containing Pt and heteropolyacids. Fuel 2011, 90, 3056-3065. [CrossRef]

37. Liu, Y.; Sotelo-Boyás, R.; Murata, K.; Minowa, T.; Sakanishi, K. Hydrotreatment of Jatropha oil to produce green diesel over trifunctional $\mathrm{Ni}-\mathrm{Mo} / \mathrm{SiO}_{2}-\mathrm{Al}_{2} \mathrm{O}_{3}$ catalyst. Chem. Lett. 2009, 38, 552-553. [CrossRef]

38. Liu, Y.; Koyano, G.; Misono, M. Hydroisomerization of $n$-hexane and $n$-heptane over platinum-promoted $\mathrm{Cs}_{2.5} \mathrm{H}_{0.5} \mathrm{PW}_{12} \mathrm{O}_{40}$ (Cs2.5) studied in comparison with several other solid acids. Top. Catal. 2000, 11, 239-246. [CrossRef]

39. Liu, Y.; Na, K.; Misono, M. Skeletal isomerization of $n$-pentane over Pt-promoted cesium hydrogen salts of 12-tungstophosphoric acid. J. Mol. Catal. A Chem. 1999, 141, 145-153. [CrossRef] 
40. Liu, Y.; Misono, M. Hydroisomerization of $n$-butane over platinum-promoted cesium hydrogen salt of 12-tungstophosphoric acid. Materials 2009, 2, 2319-2336. [CrossRef]

41. Liu, Y.; Murata, K.; Okabe, K.; Inaba, M.; Takahara, I.; Hanaoka, T.; Sakanishi, K. Selective hydrocracking of Fischer-Tropsch waxes to high-quality diesel fuel over Pt-promoted polyoxocation-pillared montmorillonites. Top. Catal. 2009, 52, 597-608. [CrossRef]

42. Liu, Y.; Koyano, G.; Na, K.; Misono, M. Isomerization of $n$-pentane and $n$-hexane over cesium hydrogen salt of 12-tungstophosphoric acid promoted by platinum. Appl. Catal. A Gen. 1998, 166, L263-L265. [CrossRef]

43. Hattori, H. Heterogenous basic catalysis. Chem. Rev. 1995, 95, 537-558. [CrossRef]

(C) 2017 by the authors. Licensee MDPI, Basel, Switzerland. This article is an open access article distributed under the terms and conditions of the Creative Commons Attribution (CC BY) license (http://creativecommons.org/licenses/by/4.0/). 